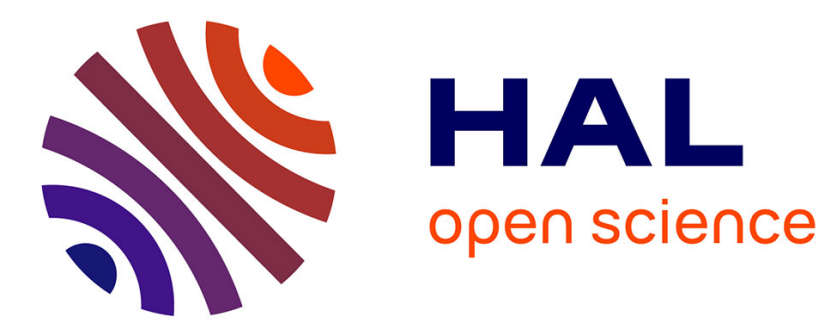

\title{
The M1 family of vertebrate aminopeptidases: Role of evolutionarily conserved tyrosines in the enzymatic mechanism of aminopeptidase $B$
}

Sandrine Cadel, Cecile Darmon, Julien Pernier, Guy Hervé, Thierry Foulon

\section{- To cite this version:}

Sandrine Cadel, Cecile Darmon, Julien Pernier, Guy Hervé, Thierry Foulon. The M1 family of vertebrate aminopeptidases: Role of evolutionarily conserved tyrosines in the enzymatic mechanism of aminopeptidase B. Biochimie, 2015, 109, pp.67-77. 10.1016/j.biochi.2014.12.009 . hal-01558872

\section{HAL Id: hal-01558872 \\ https://hal.science/hal-01558872}

Submitted on 19 Jul 2019

HAL is a multi-disciplinary open access archive for the deposit and dissemination of scientific research documents, whether they are published or not. The documents may come from teaching and research institutions in France or abroad, or from public or private research centers.
L'archive ouverte pluridisciplinaire HAL, est destinée au dépôt et à la diffusion de documents scientifiques de niveau recherche, publiés ou non, émanant des établissements d'enseignement et de recherche français ou étrangers, des laboratoires publics ou privés. 


\title{
The M1 family of vertebrate aminopeptidases: Role of evolutionarily conserved tyrosines in the enzymatic mechanism of aminopeptidase $B$
}

\author{
Sandrine Cadel ${ }^{\mathrm{a}, ~}{ }^{\text {, }}$, Cécile Darmon ${ }^{\mathrm{a}}$, Julien Pernier ${ }^{\mathrm{b}}$, Guy Hervé ${ }^{\mathrm{a}}$, Thierry Foulon ${ }^{\mathrm{a}}$ \\ a Sorbonne universités, UPMC Univ Paris 06, Institut de Biologie Paris-Seine (IBPS), FR 3631 UPMC-CNRS, BIOSIPE, BIOgenèse des SIgnaux PEptidiques, Paris, \\ France \\ ${ }^{\mathrm{b}}$ Cytoskeleton Dynamics and Motility Group, Laboratoire d'Enzymologie et Biochimie Structurale [LEBS], UPR 3082 - CNRS, Gif-sur-Yvette, France
}

Keywords:

Aminopeptidases

$\mathrm{Zn}^{2+}$-metallopeptidase

Leukotriene $\mathrm{A}_{4}$ hydrolase

M1 family

Tyrosine

\begin{abstract}
A B S T R A C T
Aminopeptidase B (Ap-B), a member of the M1 family of $\mathrm{Zn}^{2+}$-aminopeptidases, removes basic residues at the $\mathrm{NH}_{2}$-terminus of peptides and is involved in the in vivo proteolytic processing of miniglucagon and cholecystokinin-8. M1 enzymes hydrolyze numerous different peptides and are implicated in many physiological functions. As these enzymes have similar catalytic mechanisms, their respective substrate specificity and/or catalytic efficiency must be based on subtle structural differences at or near the catalytic site. This leads to the hypothesis that each primary structure contains a consensus structural template, strictly necessary for aminopeptidase activity, and a specific amino acid environment localized in or outside the catalytic pocket that finely tunes the substrate specificity and catalytic efficiency of each enzyme. A multiple sequence alignment of M1 peptidases from vertebrates allowed to identify conserved tyrosine amino acids, which are members of this catalytic backbone. In the present work, site-directed mutagenesis and 3D molecular modeling of Ap-B were used to specify the role of four fully $\left(\mathrm{Y}_{281}, \mathrm{Y}_{229}\right.$, $\mathrm{Y}_{414}$, and $\left.\mathrm{Y}_{441}\right)$ and one partially $\left(\mathrm{Y}_{409}\right)$ conserved residues. Tyrosine to phenylalanine mutations allowed confirming the influence of the hydroxyl groups on the enzyme activity. These groups are implicated in the reaction mechanism $\left(\mathrm{Y}_{414}\right)$, in substrate specificity and/or catalytic efficiency $\left(\mathrm{Y}_{409}\right)$, in stabilization of essential amino acids of the active site $\left(\mathrm{Y}_{229}, \mathrm{Y}_{409}\right)$ and potentially in the maintenance of its structural integrity $\left(\mathrm{Y}_{281}, \mathrm{Y}_{441}\right)$. The importance of hydrogen bonds is verified by the $\mathrm{Y}_{229} \mathrm{H}$ substitution, which preserves the enzyme activity. These data provide new insights into the catalytic mechanism of Ap-B in the M1 family of aminopeptidases.
\end{abstract}

Abbreviations: Ap-A, aminopeptidase A; Ap-B, aminopeptidase B; Ap-N, aminopeptidase N; Ap-O, aminopeptidase O; Ap-Q aminopeptidase Q; RNPEP-L1, arginyl aminopeptidase-like 1; CCK, cholecystokinin; ERAP, endoplasmic reticulum aminopeptidase; His-rAp-B, His-tagged rat Ap-B; IRAP, insulin-responsive aminopeptidase; L-amino acid $\beta$-NA, L-amino acid $\beta$-naphthylamide; LTA4, leukotriene A4; LTA4H, leukotriene A4 hydrolase; LTB4, leukotriene B4; PSA, puromycin-sensitive aminopeptidase; TRH-DE, thyrotropin-releasing hormone degrading enzyme.

* Corresponding author. Sorbonne universités, UPMC Univ Paris 06, Institut de Biologie Paris-Seine (IBPS), FR 3631 UPMC-CNRS, BIOSIPE, BIOgenèse des SIgnaux PEptidiques, Bâtiment A, 5ème étage, Case courrier 29, 7 Quai Saint-Bernard, 75005 Paris, France. Tel.: +33 (1) 44272172.

E-mail addresses: marie-sandrine.cadel@upmc.fr (S. Cadel), cecile.darmon@ upmc.fr (C. Darmon), pernier@lebs.cnrs-gif.fr (J. Pernier), guy.herve@upmc.fr (G. Hervé), thierry.foulon@upmc.fr (T. Foulon).

\section{Introduction}

Aminopeptidase B (Ap-B) is a $\mathrm{Zn}^{2+}$-aminopeptidase that specifically hydrolyzes the peptide bond on the carbonyl side of arginine and/or lysine residues present at the $\mathrm{NH}_{2}$-terminus of peptides [1]. Ap-B is ubiquitously expressed in vertebrates [2-4] and participates, in synergy with endoproteases, in the maturation of hormones and neuropeptides. To date, only two of its physiological substrates are identified: NRD convertase hydrolyses the glucagon into Arg-Arg-miniglucagon that is converted by Ap-B into miniglucagon, a peptide involved in the maintenance of glucose homeostasis [5]; cathepsin L hydrolyzes cholecystokinin (CCK) precursors into CCK9, which is processed by Ap-B into CCK8, a pleiotropic neuropeptide [6]. This enzyme may also be implicated in the in vivo processing of enkephalins [7] and Arg-extended forms of human insulin [8]. More recently, Ap-B was identified as a new 
cytoplasmic degrading enzyme, interfering with the maturation of a major $\mathrm{CD}^{+} \mathrm{T}$ cell epitope of the human cytomegalovirus phosphoprotein 65 [9].

Molecular cloning of rat and human Ap-B $[3,10]$ identified this protein as a member of the M1 family of aminopeptidases, belonging to the MA clan of metallopeptidases (Merops, the peptidase database; http://merops.sanger.ac.uk/). This clan, also called zincins clan [11], is divided into 39 families of endo- or exopeptidases that require a $\mathrm{Zn}^{2+}$ cation for their activity. These enzymes are unified by the presence in their primary structure of a HEXXH motif, in which histidine residues are $\mathrm{Zn}^{2+}$ ligands and glutamate has a catalytic activity. More specifically, the M1 family of aminopeptidases belongs to the MA(E) subclan, also named gluzincins clan [11] that is defined by the presence of a second glutamate, located 18 residues downstream the HEXXH motif, and acting as a third $\mathrm{Zn}^{2+}$ ligand. A tyrosine residue located 80 to 90 residues downstream the HEXXH motif completes this M1 signature. The catalytic role of this residue, together with the $\mathrm{Zn}^{2+}$ cation, is to polarize the carbonyl of the hydrolyzed peptide bond [12]. This consensus pattern, $\mathrm{HEXXHX}^{18} \mathrm{EX}^{80-90} \mathrm{Y}$, allows to classify about 2900 protein sequences in the M1 family (Merops; http:// merops.sanger.ac.uk/). About $77 \%$ of these sequences contain the motif $(G / A / H / V)(G / A) M E N$. This second pattern is usually located 22 to 38 residues upstream of the HEXXH motif and is involved in the recognition and binding of the substrate. The glutamic acid plays a key role in positioning the $\alpha$ amino group of the peptide substrate while the other residues participate in the formation of the $S 1$ pocket [12-17].

M1 aminopeptidases are largely distributed among the living world and about 55 different enzymes were predicted in Archaea, Bacteria and Eukaryotes (Plants to Vertebrates). However, most of these putative enzymes have not been characterized and no information on their cleavage specificity and enzymatic mechanism is available. In contrast, the M1 aminopeptidases expressed in mammals, 12 different enzymes, are much better characterized [Aminopeptidase A (Ap-A), B (Ap-B), N (Ap-N), O (Ap-O), Q (Ap-Q); arginyl aminopeptidase-like 1 (RNPEP-L1); Endoplasmic Reticulum Aminopeptidase 1 and 2 (ERAP1, ERAP2); Insulin-Responsive Aminopeptidase (IRAP); Leukotriene $\mathrm{A}_{4}$ hydrolase $\left(\mathrm{LTA}_{4} \mathrm{H}\right)$; Puromycin-Sensitive Aminopeptidase (PSA); ThyrotropinReleasing Hormone Degrading Enzyme (TRH-DE)].

The crystal structure of the human $\mathrm{LTA}_{4} \mathrm{H}$ was the first $3 \mathrm{D}$ structure determined in the M1 family [18]. More recently, several other structures were obtained: Ap- $\mathrm{N}$ from Escherichia coli [19], Neisseria meningitidis [20], Plasmodium falciparum [21], porcine [17] and human [22]; human ERAP1 [23]; human ERAP2 [24]. The main difference between these structures is the presence of three $\left(\mathrm{LTA}_{4} \mathrm{H}\right)$ or four (Ap-N, ERAP1 and 2) structural domains, three of them appearing similar in all proteins (Fig. 1). Consequently, these enzymes can be classified into two subfamilies according to their sizes and structural homology. The first subfamily consists of Ap-A, Ap-N, Ap-Q, ERAP1, ERAP2, IRAP, PSA and TRH-DE. The second family is composed of Ap-B, Ap-O, LTA 4 H and RNPEP-L1. In this subfamily, $\mathrm{LTA}_{4} \mathrm{H}$ is the best characterized. $\mathrm{LTA}_{4} \mathrm{H}$ is bifunctional in vivo with an epoxide hydrolase activity that converts, in the arachidonic acid pathway, the $\mathrm{LTA}_{4}$ into the inflammatory mediator leukotriene $\mathrm{B}_{4}\left(\mathrm{LTB}_{4}\right)$. The enzyme also exhibits an aminopeptidase activity with a broad specificity being able to hydrolyze substrates such as Leu, Ala or Pro-4-nitroanilide [25]. Recently, a neutrophil chemoattractant, Pro-Gly-Pro (PGP), was found to be one of the physiological substrates of the human $\mathrm{LTA}_{4} \mathrm{H}$ [26]. Paradoxically, degradation of this peptide by the enzyme facilitates the resolution of inflammation [27].

Ap-B is closely related to $\mathrm{LTA}_{4} \mathrm{H}$ (37\% sequence identity, $45 \%$ similarity). Moreover, Ap-B is bifunctional in vitro, with an aminopeptidase and a residual $\mathrm{LTA}_{4}$ hydrolase activity [10]. Since there is no Ap-B structural data available, a 3D model was built based on the crystallographic structure of $\mathrm{LTA}_{4} \mathrm{H}$ [28]. Additionally, the cocrystallization of the $\mathrm{LTA}_{4} \mathrm{H}_{(\mathrm{E} 296 \mathrm{O})}$ mutant with the R-A-R tripeptide substrate (pdb: 3B7T; 12) revealed important structural information that have allowed a better understanding of the enzymatic mechanism of Ap-B after docking of R-A-R ligand in the active site [16].

The important conserved residues for all the vertebrate peptidases of the M1 family were identified using multiple-sequence alignments. We focused our attention on conserved tyrosine residues. The roles of these amino acids in protein structures and biological functions are associated to their involvement in polar hydrogen- $\pi$ interactions (Hp- $\pi$ ) due to the hydroxyl group and to the aromatic ring, which are the Hp- $\pi$ donor and acceptor, respectively [29]. The Hp- $\pi$ interactions are specific to three amino acids $(\mathrm{H}, \mathrm{W}, \mathrm{Y})$ and may be responsible for some of the flexibility and dynamics of proteins.

Four fully conserved Tyr residues were identified, corresponding to $Y_{229}, Y_{281}, Y_{414}$ and $Y_{441}$ in Ap-B primary structure. $Y_{409}$, a partially conserved residue, was also studied. $Y_{229}$ is located in the $\beta$-sheet domain (54-237) of Ap-B (Fig. 1A). $Y_{281}, Y_{409}, Y_{414}$ and $Y_{441}$ are in the central catalytic domain (238-489), which contains the $\mathrm{G}_{298} \mathrm{GMEN}$ and $\mathrm{H}_{325} \mathrm{EXXH}\left(\mathrm{X}^{18}\right) \mathrm{E}$ motifs. More precisely, $\mathrm{Y}_{281}$ is located on a loop, and points to a $\beta$ sheet that contains the GAMEN
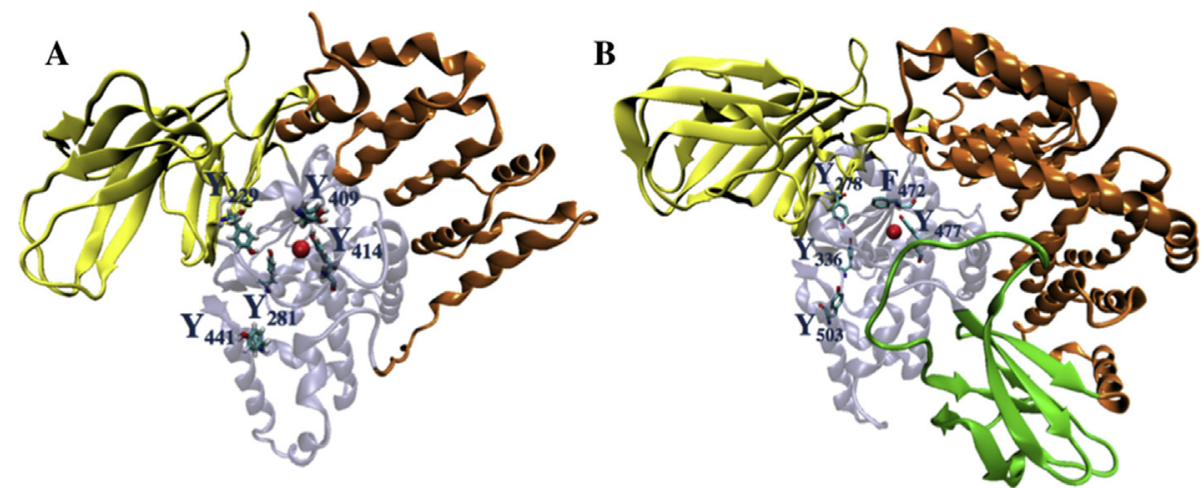

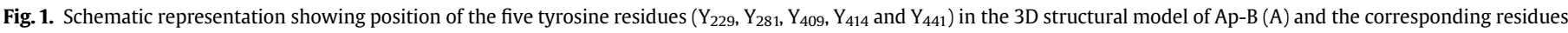

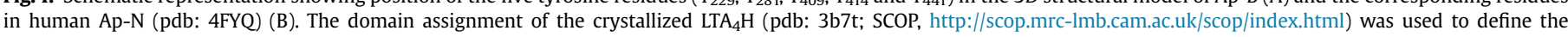

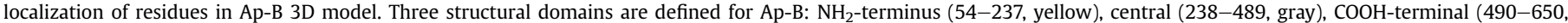

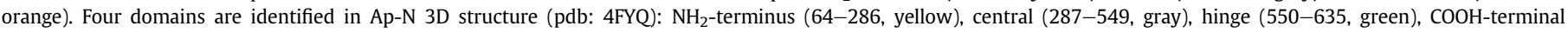
(636-967, orange) 
motif. $Y_{229}$ is on a small $\alpha$ helix between two $\beta$ strands, and head to tail with $\mathrm{Y}_{414}$. The latter is positioned on a $\alpha$ helix and oriented to the central catalytic cavity. $\mathrm{Y}_{409}$ is on a loop at the extremity of a $\alpha$ helix and in proximity of $\mathrm{Y}_{414}$. Finally, $\mathrm{Y}_{441}$ belongs to a $\alpha$ helix exposed to the protein surface. In the human Ap-N structure, the positioning of the corresponding $\mathrm{Y}$ (or F) residues is similar, $\mathrm{Y}_{278}$ is in the $\beta$-strand domain (64-286) and $\mathrm{Y}_{336}, \mathrm{~F}_{472}\left(\mathrm{Y}_{409}\right.$ in Ap-B), $\mathrm{Y}_{477}$ and $\mathrm{Y}_{503}$ are in the catalytic domain (287-549; Fig. 1B). In $\mathrm{LTA}_{4} \mathrm{H}$, $\mathrm{Y}_{383}$ (Ap-B, $\mathrm{Y}_{414}$; Ap-N, $\mathrm{Y}_{477}$; Fig. 1) is located in the active site and its mutation leads to a selective abrogation of the aminopeptidase activity [30]. $Y_{383}$ was first proposed as a proton donor to the nitrogen of the hydrolyzed peptide bond in the catalytic mechanism [30]. So far, the proposed role of $\mathrm{Y}_{383}$ is to participate in the polarization of the carbonyl bond, to increase the electropositive character of the carbon necessary for a nucleophile attack by a water molecule. This residue seems also to stabilize the intermediate oxyanion of the hydrated peptide [12]. As this tyrosine residue is conserved in the whole sequences of the M1 family, and appears to be clearly located in the active site of the crystallized aminopeptidases, such a function in the catalytic mechanism could be generalized. In the present report, mutagenesis experiments were realized to confirm the putative contribution of the Ap-B corresponding $\mathrm{Y}_{414}$ residue.

Three other tyrosine residues $Y_{229}, Y_{281}$ and $Y_{441}$ are fully conserved in the M1 family. Despite the fact that they are distant from the active site, $\mathrm{Y}$ to $\mathrm{F}$ mutations were performed to determine the importance of their hydroxyl group. In the $\mathrm{LTA}_{4} \mathrm{H}$ of Saccharomyces cerevisiae, $\mathrm{Y}_{244}\left(\mathrm{Y}_{229}\right.$ in Ap-B) is essential to the aminopeptidase activity and seems to be involved in the stabilization of the transition state [31]. More recently, the co-crystallization of the $\mathrm{LTA}_{4} \mathrm{H}$ with the RAR tripeptide substrate allowed attributing a more precise and essential function for this residue, a function that could be generalized to all the vertebrate members of the M1 family. In the case of the Ap-B, our results suggest that the hydroxyl group of $\mathrm{Y}_{229}$ is crucial for an indirect stabilization and polarization of the substrate in the Michaelis complex. The hydroxyl group of $Y_{229}$ establishes a hydrogen bond with the carboxylate of $E_{300}$ in the GAMEN motif, leading to stabilizing this crucial amino acid implicated in the anchorage of the $\mathrm{NH}_{2}$-terminus of the substrate. It can be replaced by a histidine, which is able to play similar functions [29]. In contrast, the hydroxyl groups of $Y_{281}$ and $Y_{441}$ of the Ap-B are not involved into a direct interaction with the defined residues of first shell of the active site, but rather intervene in a secondary structural stabilization, important for the enzymatic molecular dynamic.

We also focused our attention on $\mathrm{Y}_{409}$, which is replaced by a phenylalanine residue in some vertebrate $\mathrm{LTA}_{4} \mathrm{H}$ sequences (e.g. Xenopus laevis) and in aminopeptidases with four structural domains and Ap-O. The $\mathrm{Y}_{409} \mathrm{~F}$ mutation shows the importance of the hydroxyl group of $\mathrm{Y}_{409}$, an amino acid that probably potentiates the catalytic role of $\mathrm{Y}_{414}$ in the enzymatic mechanism.

This work emphasizes that amino acids of the second shell, as well as more distant residues, are essential for the chemical properties of amino acids of the first shell of the active site. They are also important in the induced fit of the substrate-enzyme complex and in the catalysis. Moreover, this analysis could highlight similarities and differences in the enzymatic mechanisms of the aminopeptidases belonging to the M1 family, which could facilitate the conception of specific inhibitors.

\section{Materials and methods}

\subsection{Multiple sequence alignments}

The BLASTP program (http://blast.ncbi.nlm.nih.gov/Blast.cgi) was used, with default parameters (BLOSUM62 matrix), to identify members of the M1 family of metalloexopeptidases. The nonredundant protein sequences database (nr; update date 2013/09), restricted to vertebrate species (taxid: 7742), was queried with the human Ap-B protein sequence [3] and 990 hits exhibiting an E value between 0 and $1 \times \mathrm{e}^{-8}$ were observed. These 990 protein sequences were aligned using CLUSTALW [http://www.ebi.ac.uk/ clustalw/]. The incomplete sequences, and/or sequences that exhibited obvious mistranslations resulting from sequencing errors, were deleted from the alignment. Among these proteins, a unique sequence per species was extracted, after checking the quality of the sequence with multiple alignments between sequences of the same aminopeptidase within the same species. Then the alignment was refined manually to minimize the number of gaps. Finally, 273 vertebrate protein sequences were aligned to check the full conservation of both signatures of the M1 family [HEXXHX ${ }^{18} \mathrm{EX}^{80-90} \mathrm{Y} ;(\mathrm{G} / \mathrm{A} / \mathrm{H} / \mathrm{V})(\mathrm{G} / \mathrm{A}) \mathrm{MEN}$ ], and to identify the fully conserved tyrosine residues. In order to provide a sequence alignment of reasonable size, only the human proteins are shown in Fig. 2.

\subsection{Site-directed mutagenesis of tyrosine residues}

The pIVEX2.4-Ap-B recombinant expression vector was used for site-directed mutagenesis [28] and mutants were generated with the QuickChange ${ }^{\circledR}$ Multi Site-Directed Mutagenesis kit according to the manufacturer specifications (Stratagene Europe, Netherlands). A single $5^{\prime}$ phosphorylated oligonucleotide per site was used in each experiment. The targeted amino acids and their corresponding mutagenic primers were the followings:

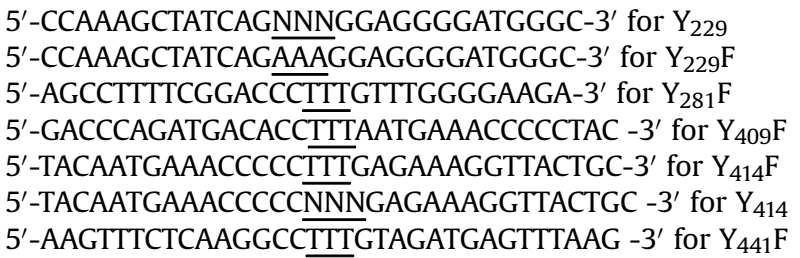

The mutagenic codon is underlined in the oligonucleotide sequence. Several mutants (Y229, Y414) were obtained using one oligonucleotide containing a degenerate codon (NNN) in order to generate mutant collection. The nucleotide sequence of each mutant was determined on both strands [Cogenics, United Kingdom].

\subsection{Production of His-tagged Ap-B in E. coli}

The pIVEX2.4-Ap-B recombinant plasmid was used to produce wild-type His-tagged rat Ap-B (His-rAp-B) and mutated His-rAp-B with a T7 promoter-driven system and a BLi5 E. coli strain as described previously [28]. Briefly, $800 \mu \mathrm{L}$ of SOB medium with $20 \%$ glucose were inoculated with Bli5 cells harboring the pIVEX2.4-Ap-B plasmid or mutants and incubated $1 \mathrm{~h}$ at $37{ }^{\circ} \mathrm{C}$ under agitation, then supplemented with $25 \mu \mathrm{g} \cdot \mathrm{mL}^{-1}$ chloramphenicol and $100 \mu \mathrm{g} \mathrm{mL}^{-1}$ ampicillin and incubated overnight at $37{ }^{\circ} \mathrm{C}$ under agitation. The overnight culture was diluted to $1: 50$ with $50 \mathrm{~mL}$ of fresh LB medium containing $100 \mu \mathrm{g} \mathrm{mL}^{-1}$ ampicillin and was grown under vigorous shaking at $37^{\circ} \mathrm{C}$ until the $\mathrm{OD}_{600}$ reached 0.6. Isopropyl $\beta$-D-1-thiogalactoside (Sigma-Aldrich, France) was added to a final concentration of $1 \mathrm{mM}$ and the expression culture was grown overnight at $25^{\circ} \mathrm{C}$ under agitation. Cells were harvested by centrifugation at $4500 \times \mathrm{g}$ for $20 \mathrm{~min}$ and stored at $-20^{\circ} \mathrm{C}$. For a preliminary screening of the activity of the mutant compared to the wild type enzyme, $200 \mu$ l of competent Bli5 cells were transformed with $300 \mathrm{ng}$ of plasmid. Then the 


\begin{tabular}{|c|c|c|}
\hline RAP1_944aa & & \\
\hline IRAP_ $1026 a a$ & YLVAFIVGEMKNLSQDVN-GTLVSIYAVPEKI--GQVHHALETTVKLLEFYQNYFEIQYPLKKLDLVAI & $\overline{432}$ \\
\hline Ap-A-959aa & YLVCFAVHQFDSVERISNSGKPLTIYVQPEQK--HTAEYAANITKSVFDYFEEYFAMNYSLPKLDKIAI & 361 \\
\hline PSA $\overline{9} 21 \mathrm{aa}$ & TYLVAFVVGEYDFVETRSKDGVCVRVYTPVGKA--EQGKFALEVAAKTLPFYKDYFNVPYPLPKIDLIA: & 320 \\
\hline ApQ_991aa & PTYLVAFVICDYDHVNRTER-GKEIRIWARKDAIANGSADFALNITGPIFSFLEDLFNISYSLPKTDIIALP-SF & 383 \\
\hline TRH DE 10 & STYYLAWAICNFTYRETTTKSGVVVRLYARPDAIRRGSGDYALHITKRLIEFYEDYFKVPYSLPKIDLLAVP-KHI & 463 \\
\hline$\overline{\text { LTA4H } 6}$ & ALVVGALESRQIGPRT----I & $\overline{272}$ \\
\hline
\end{tabular}
(229)

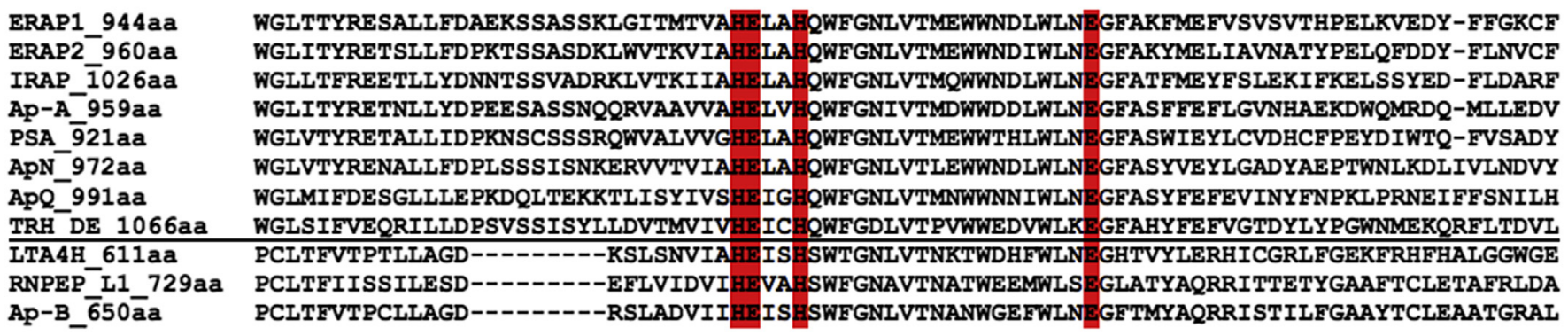

ERAP1 944aa

ERAP2-960aa

IRAP 1026aa

Ap-A 959aa

PSA_921aa

ApN 972aa

ApQ_991aa

TRH DE 1066aa

LTA4H_611aa

RNPEP I1 729aa

Ap-B_ $\overline{6} 50 \bar{a} a$
DAM-EVDALNSSHPVSTP---VENPAOIREMFDDVSYEKGACILNMLRDYLSADA-FKSGIVQYLOKYSYKNTKNEDLWNSMASI EVI-TKDSLNSSRPISKP---AETPTQIQEMFDEVSYNKGACILNMLKDFLGEEK-FQKGIIQYLKKFSYRNAKNDDLWSSLSNS KTM-KKDSLNSSHPISSSS--VQSSEQIEEMFDSLSYFKGASLLLMLKTYLSEDV-FQHAIVLYLHNHSYASIQSDDLWDSFNEV LPVQEDDSLMSSHPIVVT---VSTPAEITSVFDGISYSKGAS ILRMLEDWITPEK-FQKGCQIYLEKYQFKNAKTSDFWAALEEA TRAQELDALDNSHPIEVS---VGHPSEVDEIFDAISYSKGASVIRMLHDYIGDKD-FKKGMNMYLTKFQQKNAATEDLWESLENA RV-MAVDALASSHPLSTPASEVNTPAOISELFDSISYSKGASVLRMLSSFLTEDL-FKKGLASYLHTFAYQNTIYLDLWDHLQEA NI-LREDHALVTRAVAMKVENFTKTSEINELFDLFTYSKGASMARMLSSFLNEHL-FVSALKSYLKTFSYSNAEQDDLWRHFQMA HEVMLLDGLASSHPVS---OEVLOATDIDRVFDWIAYKKGAALIRMLANFMGHSV-FQRGLODYLTIHKYGNAARNDLWNTLSEA LQNSIKTFGET-HPFTKLVVDLTD-VDPDVAYSSVPYEKGFALLFYLEQLLGGPEVFLGFLKAYVEKFSYKSITTDDWKDFLYSH LHRQMKLLGED-SPVSKLQVKLEPGVNPSHLMNLFTYEKGYCFVYYLSQLCGDPQRFDDFLRAYVEKYKFTSVVAQDLLDSFLSF LR-QHMDITGEEHPLNKLRVKIEPGVDPDDTYNETPYEKGFCFVSYLAHLVGDQDQFDNFLKAYVDEFKFQSILADDFLEFYLEY (409) (414)
(441)

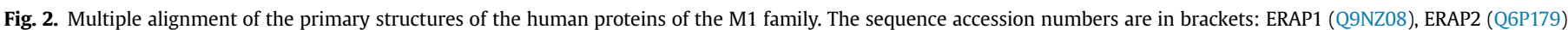

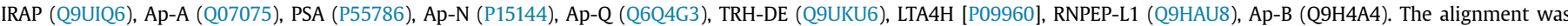

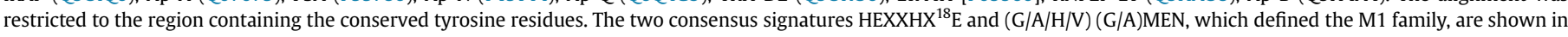

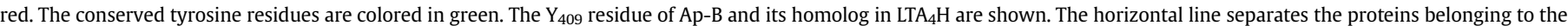
two subfamilies of the M1 peptidases described in the introduction section.

protocol was identical to that described above except that the protein was expressed in a $2 \mathrm{ml}$ final volume and the expression culture was grown $2 \mathrm{~h}$ at $37{ }^{\circ} \mathrm{C}$ under agitation. Cells were then harvested by centrifugation at $4500 \times \mathrm{g}$ for $5 \mathrm{~min}$ and the pellet was resuspended in $200 \mu \mathrm{l}$ of BugBuster master mix (Novagen, Merck Chemicals, United Kingdom). The samples were incubated $10 \mathrm{~min}$ at room temperature under agitation and centrifuged $20 \mathrm{~min}$ at $10,000 \times \mathrm{g}$. The supernatant was removed to perform the enzyme activity assays.

\subsection{Purification of the recombinant His-tagged $A p-B$ and mutants}

pIVEX2.4-Ap-B transformed cell pellets from an expression culture of $100 \mathrm{~mL}$ (see above) were resuspended in $10 \mathrm{~mL}$ of lysis buffer $(0.5 \mathrm{M} \mathrm{NaCl}, 20 \mathrm{mM}$ imidazole, $20 \mathrm{mM}$ Tris- $\mathrm{HCl} \mathrm{pH} 8)$ and sonicated, at 40 Mcycles, 5 times during $30 \mathrm{~s}$ at $4{ }^{\circ} \mathrm{C}$ in an ice water bath. The extract was centrifuged at $10,000 \times \mathrm{g}$ for $1 \mathrm{~h}$ at $4{ }^{\circ} \mathrm{C}$ to pellet the cellular debris. The supernatant was collected, filtered on a $0.22 \mu \mathrm{M}$ filter unit (Millex GU, Millipore, Ireland) and applied during $1 \mathrm{~h}$ to a $1 \mathrm{~mL}$ Histrap column (GE Healthcare Life Sciences, France), which was pre-equilibrated with $10 \mathrm{~mL}$ of binding buffer ( $20 \mathrm{mM}$ imidazole, $0.5 \mathrm{M} \mathrm{NaCl}, 20 \mathrm{mM}$ Tris $-\mathrm{HCl}$, $\mathrm{pH}$ 8). The column was washed with $10 \mathrm{~mL}$ of binding buffer. Finally, the His-tagged purified protein was eluted using a $40 \mathrm{~mL}$ linear imidazole gradient varying between 20 and $200 \mathrm{mM}$. Purified protein was concentrated and equilibrated in $50 \mathrm{mM}$ borate buffer, pH 7.4, using Amicon system (Ultra PL-10, 10,000 NMWL; Millipore, Ireland). Purified protein was concentrated and equilibrated in $50 \mathrm{mM}$ borate $\mathrm{pH} 7.4$ using Amicon system (Ultra PL-10, 10,000 NMWL; Millipore, Ireland). The concentration of the purified protein was calculated using its molar absorbance coefficient $(107,260$ at $280 \mathrm{~nm})$ with a spectrophotometer (NanoDrop, Thermo Scientific, France).

\subsection{SDS-PAGE, protein staining and western blotting}

Aliquots of protein extracts or purified proteins (see above) were run under reducing and denaturing conditions on an $8 \%$ SDS-PAGE. SDS-PAGEs were stained with silver salts to visualize total or purified proteins [28]. For western blotting, proteins were transferred to a nitrocellulose membrane $(0.45 \mu \mathrm{m}$, Schleicher \& Schuell, Germany) using a semi-dry blotting apparatus (Hoefer scientific instruments, USA). The rat Ap-B was detected with a specific anti-Ap-B polyclonal serum [1] at a dilution of 1:2000. Antigen-antibody complexes were visualized using a goat alkaline phosphatase-conjugated secondary antibody and an NBT-BCIP mixture (Sigma-Aldrich, France). 


\subsection{Enzyme activity assays}

\subsubsection{Using chromogenic substrate}

Ap-B activity was determined using L-amino acid $\beta$-naphthylamide substrates (L-Arg $\beta$-NA; Sigma-Aldrich, France). Standard assays were realized at $37{ }^{\circ} \mathrm{C}$ for $30 \mathrm{~min}$ in $100 \mathrm{mM}$ borate $\mathrm{pH} 7.4,150 \mathrm{mM} \mathrm{NaCl}$, containing $0.2 \mathrm{mM}$ L-Arg $\beta$-NA. Hydrolysis was interrupted by addition of $60 \mu \mathrm{L}$ of freshly prepared solution of Fast Garnet (GBC salt $1 \mathrm{mg} / \mathrm{mL}$ in $1 \mathrm{M}$ sodium acetate, $\mathrm{pH}$ 4.2, 10\% Tween; Sigma-Aldrich, France). The absorbance was read at $535 \mathrm{~nm}$ using a microplate spectrophotometer (ASYS UVM340, Austria). For the preliminary screening of the activity of the mutants, tests were realized with $4 \mu \mathrm{l}$ of the BugBuster extract (see Production of His-tagged Ap-B in E. coli section), which also contains an Ap- $\mathrm{N}$ activity. Therefore, the activity assays were also performed with Ap-B (arphamenine A and $\mathrm{B}$, at a $2.5 \mu \mathrm{M}$ final concentration) or $\mathrm{Ap}-\mathrm{N}$ (amastatin, at a $2.5 \mu \mathrm{M}$ final concentration) specific inhibitors. The activity with the extract containing wild-type enzyme is used as a reference, and allowed calculating the percentage of activity of the mutants. The use of arphamenine A and B, and of amastatin allows calculating a relative percentage of activity of Ap-B and Ap-N in the wild-type extract, which is compared to that obtained with the different mutant extracts. The average of three independent experimental determinations was calculated, except for $\mathrm{Y}_{229} \mathrm{~V} / \mathrm{I}$, due to a weak activity: $\mathrm{Y}_{229} \mathrm{~V}, \mathrm{Y}_{229} \mathrm{~V}$ - or I-arphamenine $\mathrm{B}, 13$ independent experimental values; $\mathrm{Y}_{229} \mathrm{~V}$-amastatin, 11 values; $\mathrm{Y}_{229} \mathrm{I}, \mathrm{Y}_{229} \mathrm{I}$-amastatin, 14 values; $\mathrm{Y}_{229} \mathrm{I}$ - or V-arphamenine A, 4 values. Determinations of the kinetic constants of Ap-B were realized in triplicate with $250 \mathrm{ng}$ of purified protein. After $5 \mathrm{~min}$ of preincubation of the enzyme at $37{ }^{\circ} \mathrm{C}$ in the reaction buffer, the substrate was added at different concentrations $(20-300 \mu \mathrm{M}$ and the reaction was stopped after $8 \mathrm{~min}$ of incubation at $37^{\circ} \mathrm{C}$. The kinetic constants for the enzymatic reaction of Ap-B with LArg $\beta$-NA were estimated from Lineweaver-Burk plots of $1 / \mathrm{v}$ against $1 /(\mathrm{S})$ and Eadie-Hofstee plots of $v$ against $v /(S)$ in the substrate concentration range $0-200 \mu \mathrm{M}$. For the determination of the $\mathrm{IC}_{50}$ of the arphamenine $\mathrm{A}$ and $\mathrm{B}$ inhibitors with the wild type and the $\mathrm{Y}_{229} \mathrm{H}$ mutant, tests were performed in triplicates with $250 \mathrm{ng}$ of enzyme, different concentrations of inhibitors (between $2 \mathrm{nM}$ and $10 \mu \mathrm{M}$ ) and $200 \mu \mathrm{M}$ of L-Arg $\beta$-NA substrate. Assays were realized with a $5 \mathrm{~min}$ preincubation at $37{ }^{\circ} \mathrm{C}$ without the substrate and an $8 \mathrm{~min}$ incubation at $37{ }^{\circ} \mathrm{C}$ with the added substrate. Tests of inhibition by arphamenine $\mathrm{A}$ and $\mathrm{B}$, bestatin and amastatin on the $\mathrm{Y}_{409} \mathrm{~F}$ mutant and the wild type enzyme were realized in the same conditions with $700 \mathrm{ng}$ and $250 \mathrm{ng}$ of protein, respectively. To assess the effects of $\mathrm{pH}$, the activity tests were carried out with $250 \mathrm{ng}$ of enzyme and $200 \mu \mathrm{M}$ final of L-Arg $\beta-\mathrm{NA}$, in a $100 \mathrm{mM}$ phosphate-150 mM $\mathrm{NaCl}$ buffer ( $\mathrm{pH}$ range $6.2-8.3$ ) or in a $100 \mathrm{mM}$ borate- $150 \mathrm{mM}$ $\mathrm{NaCl}$ buffer ( $\mathrm{pH}$ range $7.8-8.9$ ). The tests were carried out $8 \mathrm{~min}$ at $37^{\circ} \mathrm{C}$.

\subsubsection{Using peptide substrate}

Enzymatic tests were performed using $600 \mathrm{ng}$ of protein, $5 \mu \mathrm{g}$ of Arg $_{0}$-Leu 5 -enkephalin substrate in a total volume of $100 \mu \mathrm{l}$ containing $50 \mathrm{mM}$ Tris $-\mathrm{HCl}, \mathrm{pH}$ 7.4. The reaction was stopped after $17 \mathrm{~h}$ by addition of trifluoroacetic acid (TFA), $0.3 \%$ final. The samples were injected on a C18 column (5 $\mu \mathrm{m}$ diameter; UP5WRP-25K INTERCHROM; Interchim, France) combined with an HPLC (Waters, USA). Peptides are eluted with a gradient of acetonitrile (0.7\% TFA) from 20 to $60 \%$ in water (0.1\% TFA) with an increment of $1 \%$ per minute and a flow rate of $1 \mathrm{ml}$ per minute (total time $40 \mathrm{~min}$ ).

\section{Results}

\subsection{Identification of conserved tyrosine residues in the M1 family}

A multiple sequence alignment of vertebrate proteins belonging to the M1 family of aminopeptidases was performed to establish the basis for site-directed mutagenesis studies. In addition to both signatures, (G/A/H/V) (G/A)MEN and HEXXHX ${ }^{18} \mathrm{EX}^{80-90} \mathrm{Y}$, already defined for this family (Fig. 2), several other residues appear to be fully conserved in these sequences. Among them, four tyrosine residues are generally conserved, corresponding to $\mathrm{Y}_{229}, \mathrm{Y}_{281}, \mathrm{Y}_{414}$ and $\mathrm{Y}_{441}$ in the Ap-B sequence (Fig. 2).

This alignment of 273 sequences allows to calculate the percentages of conservation for these residues: $Y_{229}, 93 \%$; $Y_{281}, 93 \%$; $\mathrm{Y}_{414}, 100 \% ; \mathrm{Y}_{441}, 93 \%$. These percentages would be $100 \%$ without the sequences of the Ap-O. This protein appears to be an exception in the M1 family, and is probably an example of convergent evolution.

Indeed, Ap-O has about 20-25\% sequence identity with the Ap-B and $\mathrm{LTA}_{4} \mathrm{H}$, a percentage that drops to $17-18 \%$ with the other family members. Its primary structure retains the HEXXHX ${ }^{18} \mathrm{EX}^{80-90} \mathrm{Y}$ motif, but lost the (G/A/H/V) (G/A)MEN, wherein only methionine is conserved. Ap-O sequences were thus deleted from the alignment allowing to obtain four fully conserved tyrosine residues in the M1 family. A simplified alignment presenting only the human proteins is shown in Fig. 2. We also focused our attention on a fifth tyrosine residue $\left(A p-B, Y_{409}\right)$ that is conserved in the Ap-B and most of the $\mathrm{LTA}_{4} \mathrm{H}$ vertebrate sequences, and replaced by a phenylalanine residue in the other aminopeptidase sequences, except for RNPEP-L1 (M vs. Y or F). The interest for $\mathrm{Y}_{409}$ is linked to its proximity with $\mathrm{Y}_{414}$. Some other tyrosine residues are specifically conserved in the sequences of Ap-B, $\mathrm{LTA}_{4} \mathrm{H}$ and RNPEP-L1, such as the $\mathrm{Y}_{286}, \mathrm{Y}_{352}$ and $\mathrm{Y}_{423}$ Ap-B residues (Fig. 2). These amino acids should also deserve special attention in the future.

\subsection{Site-directed mutagenesis and enzymatic activity of the mutants}

The $Y_{229}, Y_{281}, Y_{414}$ and $Y_{441}$ residues in the Ap-B primary structure were subjected to site-directed mutagenesis. The $\mathrm{Y}_{409} \mathrm{~F}$ substitution was also performed. All recombinant proteins were expressed in the Bli5 strain of E. coli and mutants retaining enzymatic activity were purified. In all cases, the SDS-PAGEs of purified products showed a major band corresponding to wild type Ap-B, as observed after using western blotting with the $\mathrm{Y}_{229} \mathrm{H}$ mutant, chosen as an example on Fig. 3.

A crude homogenate of $E$. coli was used to estimate the relative enzymatic activity of the wild-type Ap-B and of each different mutant (Fig. 4). Assays were realized with L-Arg $\beta$-NA as a substrate and the resulting activity is due to both the presence of Ap-B and of endogenous Ap- $\mathrm{N}$ that is also expressed in the crude extracts (Fig. 4, first column of each different protein). A second series of tests was performed in the presence of the Ap-N inhibitor amastatin to estimate the Ap-B activity (Fig. 4, column Ap-B). Conversely, two other series of tests were also realized in the presence of arphamenine $A$ and $B$, both Ap-B inhibitors, to estimate the level of Ap-N activity (Fig. 4, columns Ap-N-1 and Ap-N-2, respectively). This first step is used to identify mutations, which show a modified activity relative to that of the wild-type enzyme. The resulting activity has to be sufficient and stable to allow the purification and the analyze of the catalytic parameters of the "mutated enzyme."

As seen in Fig. 4, the aminopeptidase activity of the wild type extract is essentially due to Ap-B [about 90\% of Ap-B activity]. Except for $\mathrm{Y}_{229} \mathrm{H}$ (about $80 \%$ of Ap-B activity) and partially for $\mathrm{Y}_{441} \mathrm{~F}$ (about $25 \%$ of Ap-B activity), the other mutations dramatically 


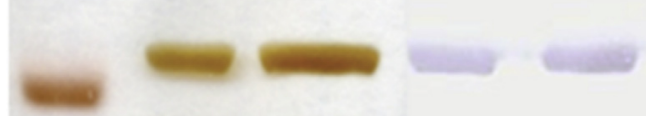

55

\section{3}

Fig. 3. Expression and purification of recombinant wild type Ap-B and $\mathrm{Y}_{229} \mathrm{H}$ proteins. (A) $\mathrm{Y}_{229} \mathrm{~F}$ and wild type His-tagged Ap-B were expressed in E. coli and purified using Ni-NTA column. One $\mu \mathrm{g}$ of each sample were run on an $8 \%$ SDS-PAGE and stained with silver salts. (B) A similar SDS-PAGE was transferred to a nitrocellulose membrane and Ap-B was detected with a specific anti-Ap-B polyclonal antibody [1]. A narrow band of lower molecular weight is detectable on the silver stained gel and absent on the western blot. This band is typically observed in the experiments of Ap-B purification and it would correspond to a residual presence of GroEL. Relative molecular masses are indicated in kilo Daltons near the prestained molecular mass markers (M).
Table 1

Catalytic parameters of wild type Ap-B and of $\mathrm{Y}_{229} \mathrm{~F}$ and $\mathrm{Y}_{229} \mathrm{H}$ mutant towards L-Arg $\beta$-NA substrates. ${ }^{\text {a }}$

\begin{tabular}{lcll}
\hline & $\mathrm{K}_{\mathrm{M}}[\mu \mathrm{M}]$ & $\mathrm{k}_{\text {cat }}\left[\mathrm{s}^{-1}\right]$ & $\mathrm{k}_{\text {cat }} / \mathrm{K}_{\mathrm{M}} \times 10^{6}\left[\mathrm{M}^{-1} \mathrm{~s}^{-1}\right]$ \\
\hline Wild type & $162 \pm 37$ & $25 \pm 4$ & 0.154 \\
$\mathrm{Y}_{229} \mathrm{H}$ & $60 \pm 6.7$ & $9.4 \pm 3.6$ & 0.157 \\
$\mathrm{Y}_{409} \mathrm{~F}$ & $98.7 \pm 17$ & $4.8 \pm 1$ & 0.048 \\
$\mathrm{Y}_{441} \mathrm{~F}$ & $45.3 \pm 7.6$ & $2.3 \pm 0.2$ & 0.051 \\
\hline
\end{tabular}

${ }^{a}$ The results $\left(\mathrm{K}_{\mathrm{m}}\right.$ and $\left.\mathrm{k}_{\mathrm{cat}}\right)$ are the mean of three experimental points from different independent experiments ( 2 for wild type Ap- $\mathrm{B}, 3$ for $\mathrm{Y}_{229} \mathrm{H}, 2$ for $\mathrm{Y}_{409} \mathrm{~F}$ and 3 for $\mathrm{Y}_{441} \mathrm{~F}$ ). The standard deviation (SD) is calculated.

affect Ap-B activity. Indeed, no significant enzymatic activity was observed with the $\mathrm{Y}_{229} / \mathrm{F} / \mathrm{V} / \mathrm{I} / \mathrm{L}, \mathrm{Y}_{281} \mathrm{~F}$ and $\mathrm{Y}_{414} \mathrm{~F} / \mathrm{H} / \mathrm{S} / \mathrm{R}$ mutations (Fig. 4; Table 1). The residual activity of the $\mathrm{Y}_{409} \mathrm{~F}$ mutant seems to be less sensitive to arphamenine $A$ and B. Contrary to $\mathrm{Y}_{414} \mathrm{H}, \mathrm{Y}_{229} \mathrm{H}$ substitution does not affect the activity and the inhibitor sensitivity of the mutated Ap-B.

These results show that the hydroxyl groups of these tyrosine residues are necessary for the enzyme activity, since the mutation of tyrosine to phenylalanine is deleterious for $\mathrm{Y}_{414} \mathrm{~F}$ activity and affects to a lesser extend the activities of $\mathrm{Y}_{229} \mathrm{~F}, \mathrm{Y}_{281} \mathrm{~F}, \mathrm{Y}_{409} \mathrm{~F}$ and $\mathrm{Y}_{441} \mathrm{~F}$. Interestingly, in $\mathrm{Y}_{229} \mathrm{H}$, but not in $\mathrm{Y}_{414} \mathrm{H}$, the histidine imidazole group could replace the tyrosine phenol group.

A residual Ap-B activity could sometimes be observed in the crude E. coli extracts containing the mutants $\mathrm{Y}_{229} \mathrm{~F}, \mathrm{Y}_{281} \mathrm{~F}, \mathrm{Y}_{409} \mathrm{~F}$, $\mathrm{Y}_{414} \mathrm{H}$ and $\mathrm{Y}_{441} \mathrm{~F}$. These mutants were purified in order to determine their activity and to characterize their catalytic parameters. However, the activities of these purified mutants are difficult to detect and labile over time, particularly for $\mathrm{Y}_{229} \mathrm{~F}, \mathrm{Y}_{281} \mathrm{~F}$ and $\mathrm{Y}_{414} \mathrm{H}$.

Consequently, we focused our efforts on the $\mathrm{Y}_{229} \mathrm{H}, \mathrm{Y}_{409} \mathrm{~F}$ and $\mathrm{Y}_{441} \mathrm{~F}$ that exhibit a significantly higher and stable activity. Interestingly, the $\mathrm{Y}_{229} \mathrm{H}$ mutation seems to preserve the activity towards

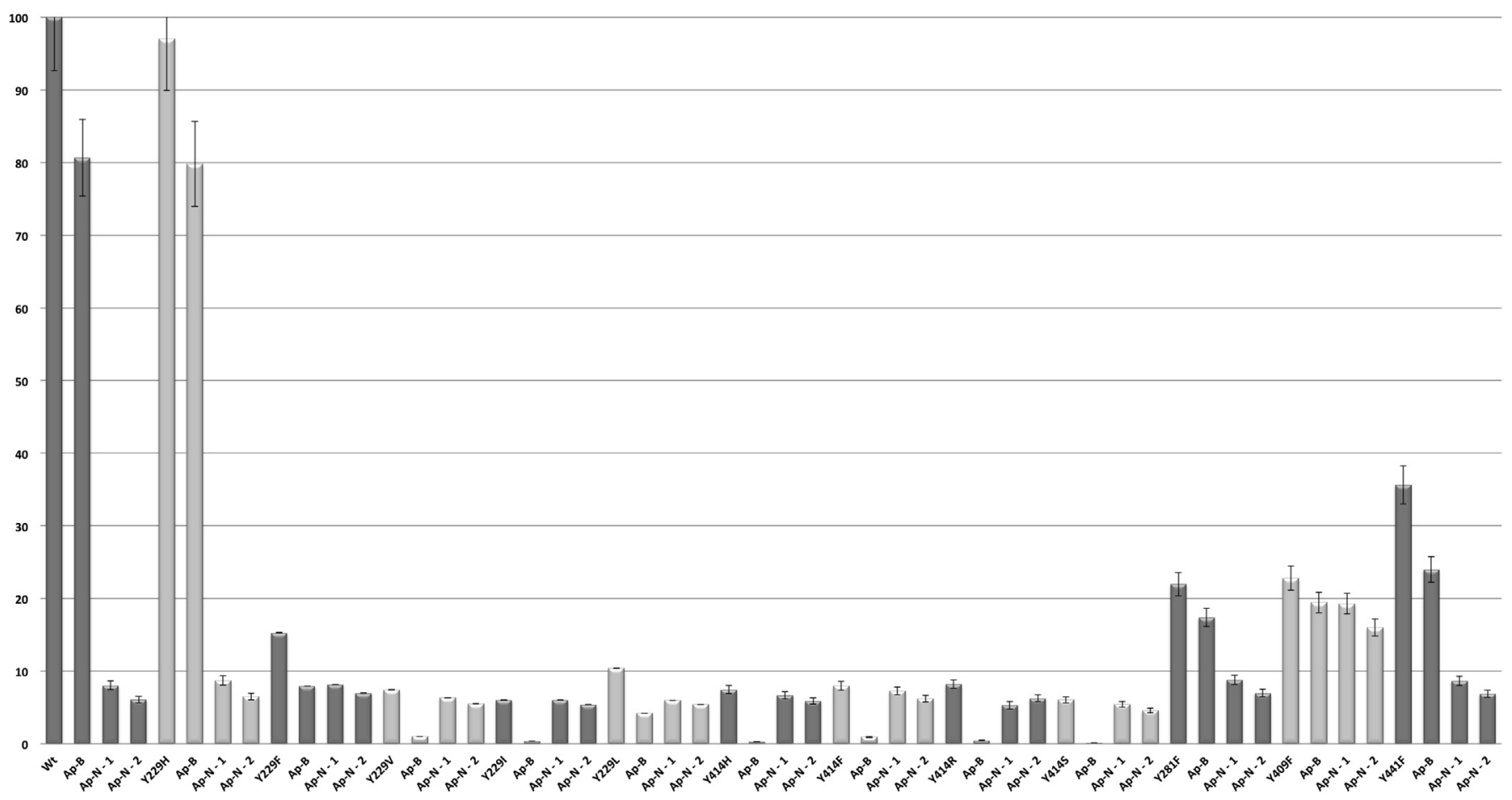

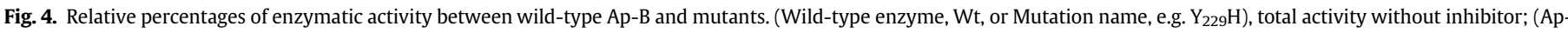

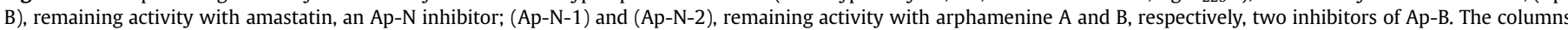

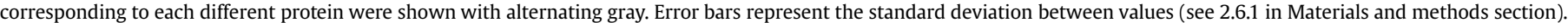

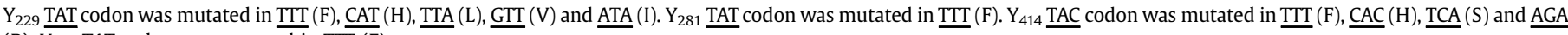
(R). $\mathrm{Y}_{441}$ TAT codon was mutated in TTT (F). 

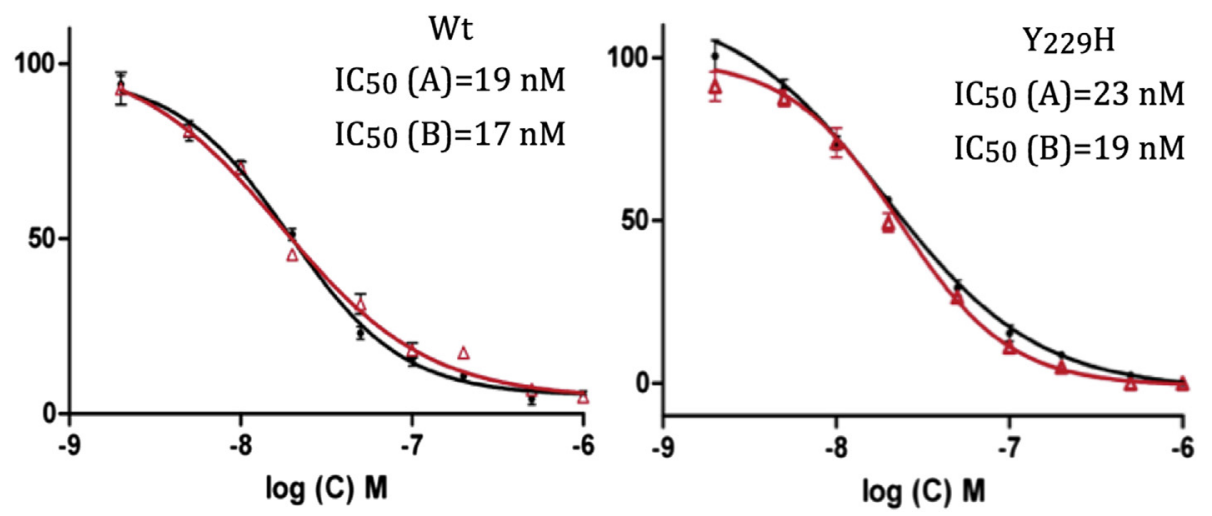

Fig. 5. Percentages of activity of the wild type Ap-B (Wt) and $\mathrm{Y}_{229} \mathrm{H}$ with different concentrations of arphamenine $\mathrm{A}(\bullet)$ or $\mathrm{B}(\Delta)$ )

L-Arg $\beta$-NA. However, compared to the wild type, an increase of the affinity (from 1.9 to 3.7 depending on the SD) and a decrease of the $\mathrm{k}_{\mathrm{cat}}$ is observed (from 1.6 to 5 ; Table 1 ). On the other hand, the catalytic efficiency is altered in the $\mathrm{Y}_{409} \mathrm{~F}$ and $\mathrm{Y}_{441} \mathrm{~F}$ mutants whose catalytic constant is decreased by a factor about 5 and 10 , respectively (Table 1 ).

The activities of wild type Ap-B and of $\mathrm{Y}_{229} \mathrm{H}$ enzyme were tested in the presence of increasing concentrations of arphamenine A and B inhibitors, which are analogous of Arg-Phe and Arg-Tyr dipeptides, respectively. As observed on Fig. 5, the $\mathrm{IC}_{50}$ are not significantly different between Ap-B and $\mathrm{Y}_{229} \mathrm{H}$. As these inhibitors are competitive, the formula $\mathrm{Ki}=\mathrm{IC}_{50} / 1+\mathrm{S} / \mathrm{Km}$ allows to calculate a Ki, which is, for the arphamenine A, $8.5 \mathrm{nM}$ for wild type Ap-B vs. $7.6 \mathrm{nM}$ for $\mathrm{Y}_{229} \mathrm{H}$, and for the arphamenine $\mathrm{B}, 10.3 \mathrm{nM}$ for wild type Ap-B vs. $8.5 \mathrm{nM}$ for $\mathrm{Y}_{229} \mathrm{H}$.

Similar tests with $\mathrm{Y}_{409} \mathrm{~F}$ showed that this mutant has lost its sensitivity towards arphamenine A and B (Fig. 6A) and towards the bestatin inhibitor (Fig. 6B). No significant difference could be observed with amastatin (Fig. 6B), an Ap-N inhibitor that has no effect on Ap-B and $\mathrm{Y}_{409} \mathrm{~F}$ enzyme activities.

\subsection{Test of activity of the $\mathrm{Y}_{229} \mathrm{H}$ enzyme with an $\mathrm{Arg}_{0^{-}} \mathrm{Leu}_{5^{-}}$} enkephalin peptide substrate

To evaluate the influence of the $\mathrm{Y}_{229} \mathrm{H}$ mutation on the enzyme activity towards a physiological substrate, enzymatic assays were performed using the $\mathrm{Arg}_{0}$-Leu $\mathrm{Len}_{5}$-enkephalin hexapeptide. The HPLC elution profile shows that the $\mathrm{Y}_{229} \mathrm{H}$ enzyme is able to hydrolyze

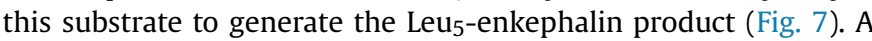
MALDI mass spectrometric analysis of the elution products confirmed the presence of the corresponding substrate (peak 1,

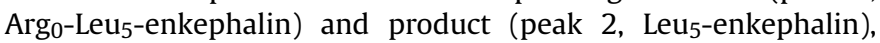
with a respective molecular mass of $712 \mathrm{Da}$ and $556 \mathrm{Da}$ (data not shown).

\subsection{Effect of $\mathrm{pH}$ on the activity of $\mathrm{Y}_{229} \mathrm{H}$ compared to that of the wild type enzyme}

Tyrosine residues are able to establish H-bonds with their hydroxyl function. Substitution of tyrosine by a histidine residue maintains this ability to form hydrogen bonds via the nitrogen in $\varepsilon$ or $\delta$ position. Since these amino acids have very dissimilar $\mathrm{pKa}$, the effect of $\mathrm{pH}$ on the activity of $\mathrm{Y}_{229} \mathrm{H}$ was tested over a $\mathrm{pH}$ range from 5.7 to 9.2 and compared to that of the wild type enzyme (Fig. 8). The $\mathrm{pH}$ dependence of $\mathrm{Y}_{229} \mathrm{H}$ is close to that of the wild type enzyme, except for a small shift towards higher $\mathrm{pH}$ in the descending part of the curve, which provokes a slight modification of the $\mathrm{pH}$ optimum activity, i.e. around 7.6 for $\mathrm{Y}_{229} \mathrm{H}$ and around 7.4 for the wild type enzyme. This showed that the $\mathrm{Y}_{229} \mathrm{H}$ mutation does not affect significantly the $\mathrm{pH}$ dependence of the enzyme and suggests that the deprotonated form of the histidine could substitute the tyrosine.

\section{Discussion}

To highlight important amino acids implicated in the structure and/or function of the M1 family aminopeptidases, we focused our attention on four particularly well conserved tyrosine residues, corresponding to $\mathrm{Y}_{229}, \mathrm{Y}_{281}, \mathrm{Y}_{414}$ and $\mathrm{Y}_{441}$ of Ap-B. Our interest also focused on a tyrosine residue existing in Ap-B $\left(\mathrm{Y}_{409}\right)$ and most of
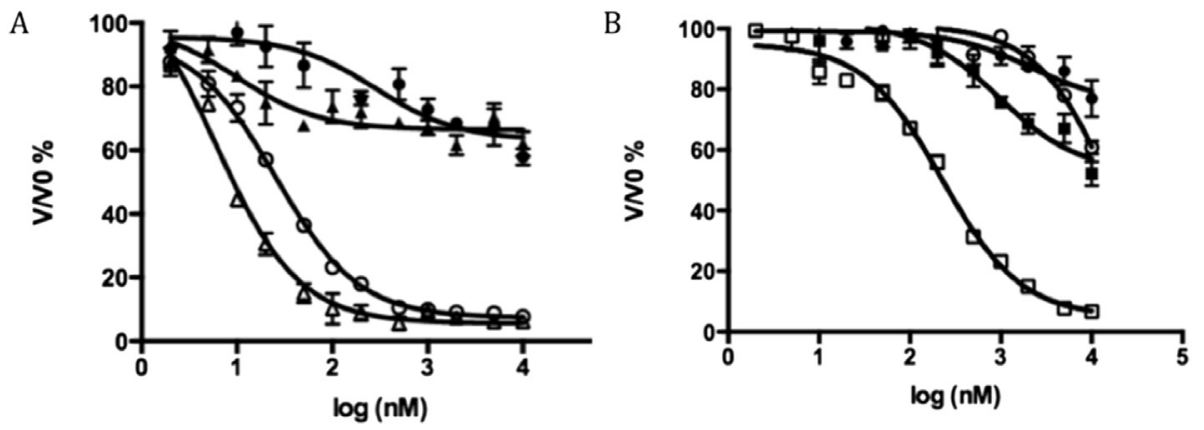

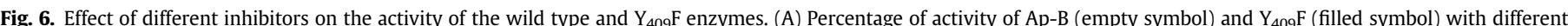

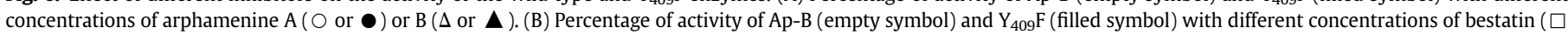
or $\square$ ) or amastatin ( $O$ or - ). The $\mathrm{IC}_{50}$ are between 22 to $29 \mathrm{nM}$ and $4-9 \mathrm{nM}$ for the arphamenine $\mathrm{A}$ and $\mathrm{B}$, respectively, and between 165 and $314 \mathrm{nM}$ for bestatin. 


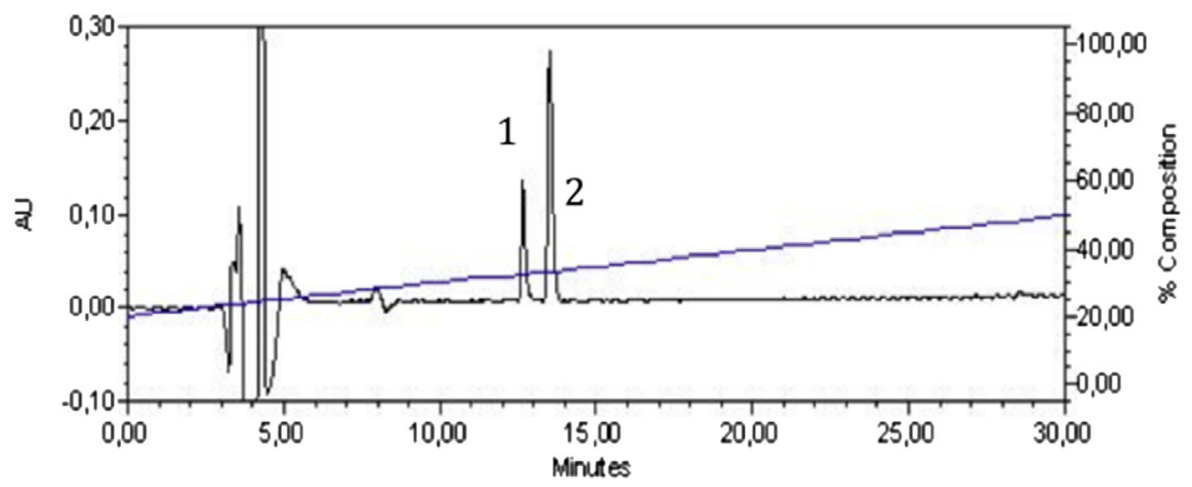

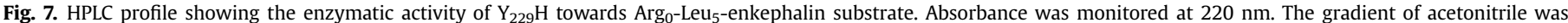
indicated as a percentage (blue line). Peak 1 corresponds to the Arg $_{0}$-Leu $\mathrm{L}_{5}$-enkephalin substrate and peak 2 to the Leu $\mathrm{u}_{5}$-enkephalin product.

the $\mathrm{LTA}_{4} \mathrm{H}$ sequences, but replaced by a phenylalanine residue in most of the other M1 sequences.

In this study, site-directed mutagenesis was performed to substitute tyrosine in order to analyze the importance of the hydroxyl group in the enzymatic mechanism. The importance of the $\mathrm{Y}_{414}$ residue is confirmed, since the $\mathrm{Y}_{414} \mathrm{~F}$ mutation abolished the enzymatic activity towards L-Arg $\beta$-NA. An expected result, since its positional counterpart in the structure of LTA $_{4} \mathrm{H}$ is suspected to take part in the polarization of the carbonyl of the hydrolyzed peptide bond. The analysis of the $\mathrm{Y}_{229} \mathrm{~F}$ mutant also showed that the catalysis process is seriously impaired. The effects on the activity using a L-Arg $\beta$-NA substrate are less pronounced with the $\mathrm{Y}_{409} \mathrm{~F}$, $\mathrm{Y}_{281} \mathrm{~F}$ and $\mathrm{Y}_{441} \mathrm{~F}$ mutants. However, their activity remains unstable.

\subsection{Tyrosine 229}

According to the results obtained with the $\mathrm{Y}_{244} \mathrm{~F}$ mutant of the $\mathrm{LTA}_{4} \mathrm{H}$ of $S$. cerevisiae [31], it was postulated that this tyrosine stabilizes the transition state of the peptidase activity. The determination of the 3D structure of different aminopeptidases allows

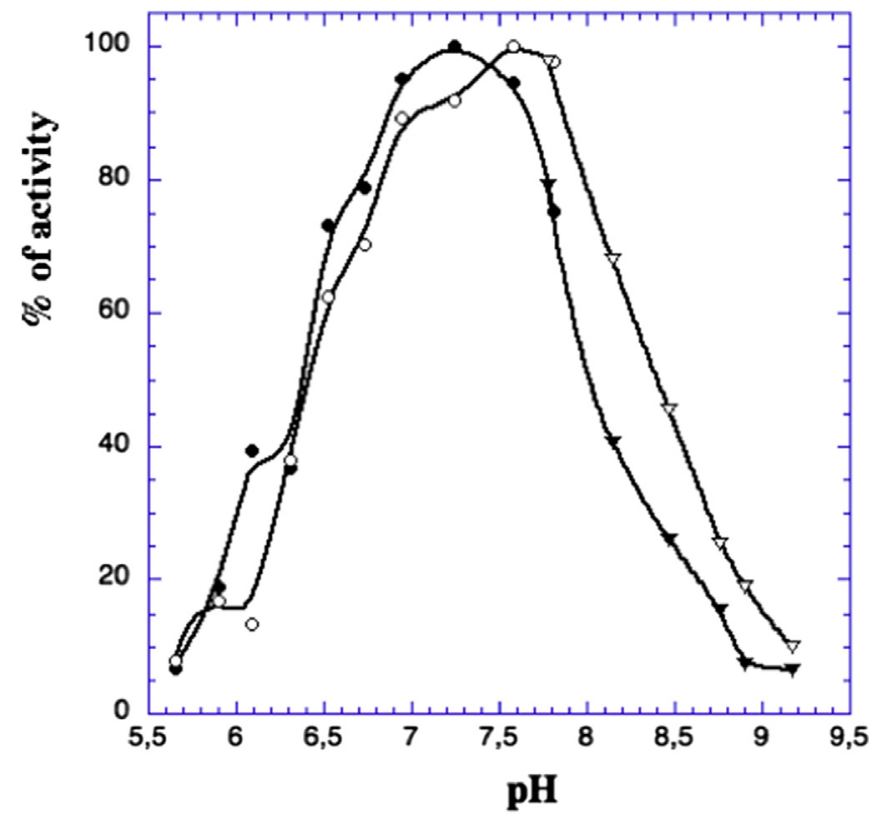

Fig. 8. Effect of pH on enzyme activity. The percentages of activity of Ap-B (filled symbol) and of $\mathrm{Y}_{229} \mathrm{H}$ (empty symbol) were determined in a phosphate buffer (round) or in a borate buffer (triangle) containing $150 \mathrm{mM} \mathrm{NaCl}$. defining more precisely the putative function of this tyrosine that corresponds to $\mathrm{Y}_{229}$ in Ap-B. Moreover, based on the 3D structure of an $\mathrm{LTA}_{4} \mathrm{H}_{[\mathrm{E} 296 \mathrm{Q}]}$ mutant in complex with an RAR substrate [12], a 3D Ap-B model with the RAR peptide docked in the active site was obtained (Fig. 9) [16] that shows that the hydroxyl group of $Y_{229}$ does not interact directly with the substrate, but can contract a hydrogen bond with $\mathrm{E}_{301}$. This essential residue, located at the end of a $\beta$ strand defined by residues of the GAMEN motif, interacts with the $\mathrm{NH}^{3+}$-terminus of the substrate (Fig. 9).

Thus, a hydrogen bond implicating the hydroxyl of $\mathrm{Y}_{229}$ to stabilize $E_{301}$ seems to be essential for the catalysis. $Y_{229}$ appears to be a crucial actor in the reaction mechanism related to aminopeptidase function. In agreement, the mutation of $Y_{229}$ into a hydrophobic residue, such as $\mathrm{Y}_{229} \mathrm{~L} / \mathrm{I} / \mathrm{V}$, abolishes the enzyme activity.

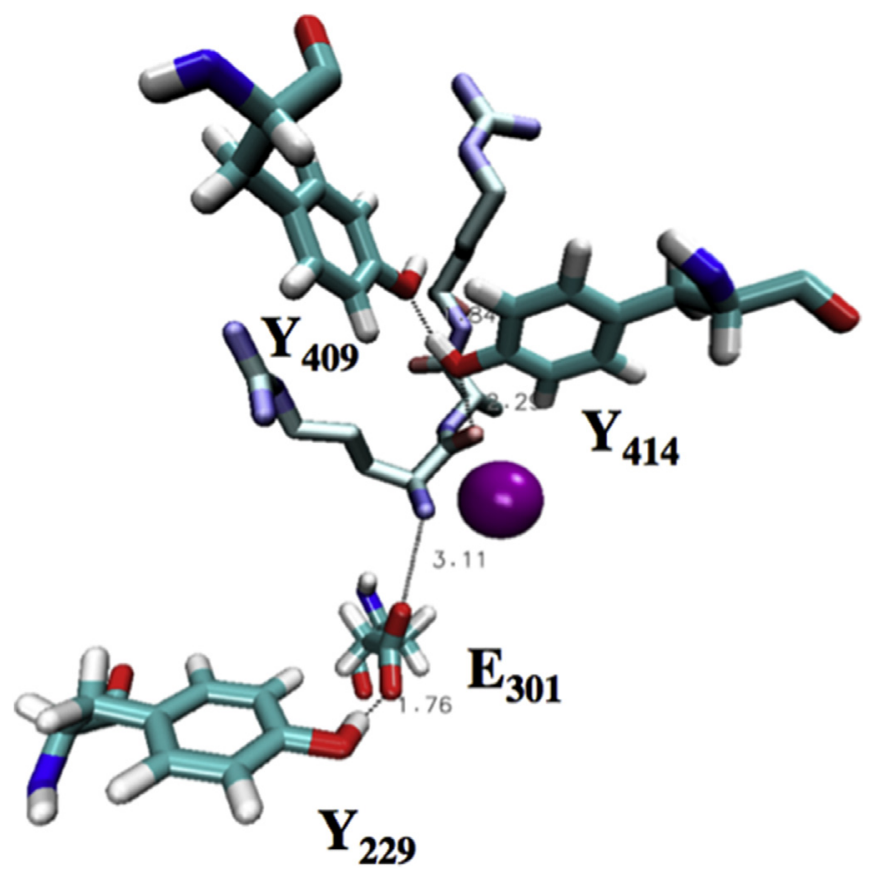

Fig. 9. Schematic representation showing the $E_{301}$ residue in the active site of the ApB. The $\mathrm{Zn}^{2+}$ cation is shown as a purple sphere. $\mathrm{E}_{301}$ interacts with the $\mathrm{NH}_{2}$-terminus of the RAR peptide substrate ( $3.11 \AA$ distance) and with the hydroxyl group of the $Y_{229}$ residue (1.76 $\AA$ distance). The $\mathrm{Y}_{414}$ residue is in proximity of the hydrolyzed peptide bond $(2.23 \AA)$. The proximity between $\mathrm{Y}_{414}$ and $\mathrm{Y}_{409}$ is shown (1.84 $\AA$ distance). The RAR tripeptide has been docked by superposition of the Ap-B and LTA $4 \mathrm{H}(\mathrm{pdb}$ : $3 \mathrm{~b} 7 \mathrm{t}$ ) structures with the DaliLite software of the Thornton group at the EMBL-EBI [16] Images of structures were performed using the Visual Molecular dynamics (VMD) software. Hydrogen bonds (dotted line) and distances are specified. 
As histidine has a steric hindrance similar to that of tyrosine residue and is susceptible to $\mathrm{Hp}-\pi$ interactions [29], the $\mathrm{Y}_{229} \mathrm{H}$ mutant was generated to test the functional equivalence of the respective side chains at this position. The catalytic efficiency towards L-Arg $\beta$-NA is not significantly modified. Thus, an imidazole group could substitute the phenol group in a defined amino acid environment. Inhibition by arphamenine $\mathrm{A}$ and $\mathrm{B}$, reported to be specific inhibitors of $A p-B$, is the same as that of the wild type enzyme. Moreover, the $\mathrm{Y}_{229} \mathrm{H}$ mutant is able to hydrolyze the peptide bond on the carboxylic side of the arginine residue of $\mathrm{Arg}_{0^{-}}$ Leu ${ }_{5}$-enkephalin. The properties of this mutant are thus similar to those of the wild type, including the sensitivity to arphamenine $A$ and $B$ and the 2.5-fold increase of activity towards L-Arg $\beta$-NA in the presence of $150 \mathrm{mM} \mathrm{NaCl}$ (data not shown). In addition, circular dichroism analysis of this mutant compared to the wild type enzyme shows no significant difference of secondary structure (data not shown). The $\mathrm{pH}$ dependence of $\mathrm{Y}_{229} \mathrm{H}$ is close to that of the wild type enzyme, suggesting that the deprotonated form of the histidine could substitute the tyrosine. Moreover, $Y_{229}$ and $E_{301}$ could also establish hydrogen bonds with a conserved asparagine residue (2.17 and 3.49 Å distance, respectively; Fig. 10). For ERAP2, an atomic interaction (3.1 $\AA$ ) has notably been observed between the corresponding residues $\mathrm{Y}_{262}$ and $\mathrm{N}_{392}$ [21]. $\mathrm{N}_{392}$ (Ap-B, $\mathrm{N}_{347}$ ) was mapped in the active site, in proximity of significant residues for catalysis such as $E_{200}$ (Ap-B, $Q_{171}$ ), $E_{337}$ (Ap-B, $E_{301}$ ) or $E_{393}$ (Ap-B, $E_{348}$ ). Since, the natural $\mathrm{N}_{392} \mathrm{~K}$ polymorphism of ERAP2 was linked with a predisposition to several human diseases, such as ankylosing spondylitis or preeclampsia $[32,33]$. A recent study showed that this $\mathrm{N}_{392} \mathrm{~K}$ substitution interferes with the stabilization of the $\mathrm{NH}_{2}$-terminus of the substrate, with an effect on the catalytic turnover $\left(k_{c a t}\right)$, the substrate specificity, but not the affinity of ERAP2 towards its substrate [34]. Therefore, these observations are

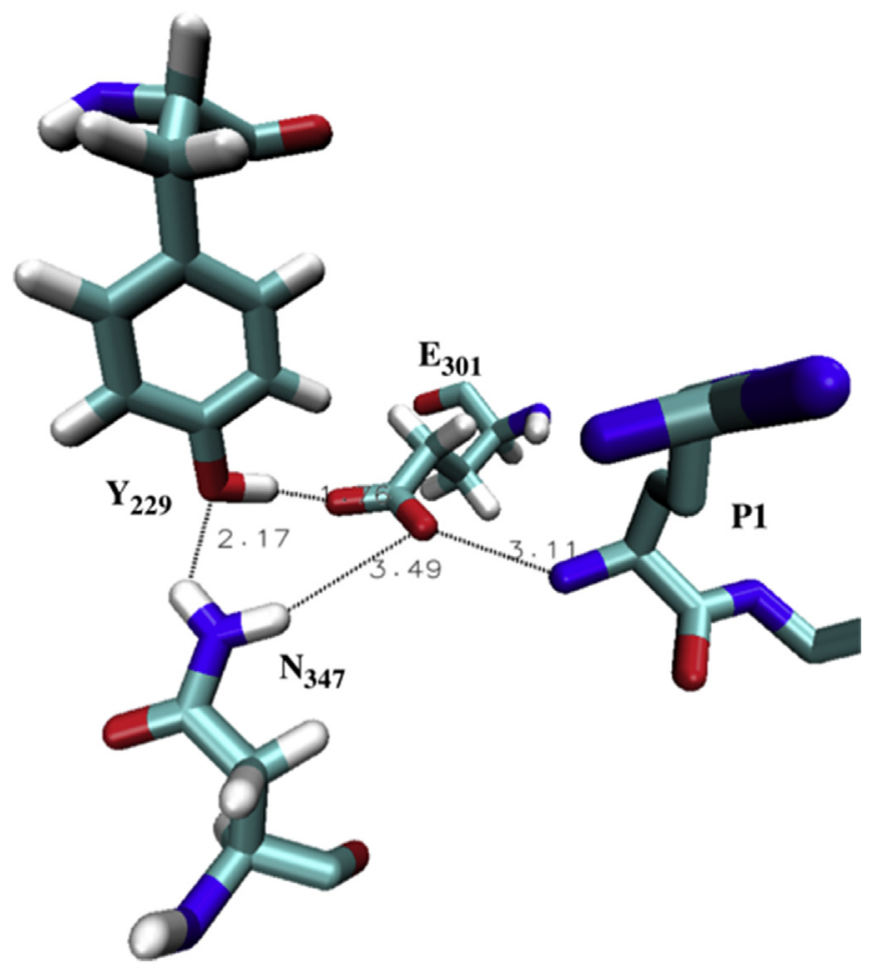

Fig. 10. Hydrogen binding network between $\mathrm{Y}_{229}, \mathrm{E}_{301}, \mathrm{~N}_{347}$ residues and the $\mathrm{NH}_{2}$ terminus of P1 of the RAR tripeptide substrate. Hydrogen bonds and distances are specified between $\mathrm{N}_{347}$ and $\mathrm{Y}_{229}\left(2.17 \AA\right.$ ), $\mathrm{N}_{347}$ an $\mathrm{E}_{301}(3.49 \AA), \mathrm{Y}_{229}$ and $\mathrm{E}_{301}(1.76 \AA$ ), $\mathrm{E}_{301}$ and the $\mathrm{NH}_{2}$-terminus of the peptide $(3.11 \AA$ ). Images of structures were performed using the Visual Molecular dynamics (VMD) software. in agreement with our results, which show that the integrity and the environment of $Y_{229}$ and $E_{301}$ residues of Ap-B are necessary for aminopeptidase activity.

\subsection{Tyrosine 414}

$\mathrm{Y}_{414} \mathrm{~F} / \mathrm{A} / \mathrm{H} / \mathrm{L} / \mathrm{R} / \mathrm{S}$ mutations led to inactive enzymes. Therefore, the $\mathrm{Y}_{414} \mathrm{H}$ replacement could not substitute the particular properties of the $\mathrm{Y}_{414}$ residue. Contrary to $\mathrm{Y}_{229} \mathrm{H}$, the histidine residue of $\mathrm{Y}_{414} \mathrm{H}$ is not in the same environment. One possible explanation could be the proximity between $\mathrm{Y}_{414}$ and the Zinc atom (4.11 $\AA$, not shown). The $\mathrm{Y}_{414} \mathrm{H}$ mutation may indeed disturb the enzymatic reaction because this histidine residue could potentially act as another chelator of the $\mathrm{Zn}^{2+}$ catalytic atom. Similar results are observed for $\mathrm{LTA}_{4} \mathrm{H}$, the corresponding $\mathrm{Y}_{38} \mathrm{H} / \mathrm{F} / \mathrm{Q}$ mutants being devoid of peptidase activity [35].

\subsection{Tyrosine 409}

The hydroxyl group of $\mathrm{Y}_{409}$ could potentially establish hydrogen bonds with $\mathrm{Y}_{414}$ (Fig. 11). $\mathrm{Y}_{409} \mathrm{~F}$ mutation affects the enzyme activity toward L-Arg $\beta$-NA, as the enzyme turnover is decreased by a factor of 5.5-6. Moreover, $\mathrm{Y}_{409} \mathrm{~F}$ has lost its sensitivity towards arphamenine A and B, as well as bestatin. The analysis of the 3D Ap-B model indicates that $\mathrm{Y}_{409}$ is essential for the role of $\mathrm{Y}_{414}$ (Fig. 11). Indeed, the proximity $\left(1.84 \AA\right.$ ) suggests that $\mathrm{Y}_{409}$ strengthens the induced polarization of the peptide bond by $\mathrm{Y}_{414}$. However, the corresponding $\mathrm{Y}_{378} \mathrm{~F}$ mutation in $\mathrm{LTA}_{4} \mathrm{H}$ reduces the peptidase activity by $57 \%$, using L-Ala 4 -nitroanilide. Consequently, the affinity, but not the enzyme turnover, is affected [36]. Moreover, the epoxide hydrolase activity of $\mathrm{Y}_{378} \mathrm{~F}$ produced, in addition to $\Delta^{6}$-cis$\Delta^{8}$-trans $\mathrm{LTB}_{4}(70-80 \%)$, a second metabolite, the $\Delta^{6}$-trans- $\Delta^{8}$-cis$\mathrm{LTB}_{4}(20-30 \%)[36]$. In some vertebrate, $\mathrm{LTA}_{4} \mathrm{H}$ has a phenylalanine residue instead of a tyrosine at the corresponding position. This is the case for the $X$. laevis $\mathrm{LTA}_{4} \mathrm{H}$ that produces this second metabolite [37]. The production of this $\mathrm{LTB}_{4}$ isomeric compound is abolished by the corresponding $\mathrm{F}_{375} \mathrm{Y}$ mutation (human $\mathrm{LTA}_{4} \mathrm{H}, \mathrm{Y}_{378}$; Ap-B, $Y_{409}$ ) [38]. A role for the $Y_{375}$ hydroxyl group in the stabilization by a hydrogen bond of the $\mathrm{Y}_{380}$ catalytic residue $\left(\mathrm{Ap}-\mathrm{B}, \mathrm{Y}_{414}\right)$ was

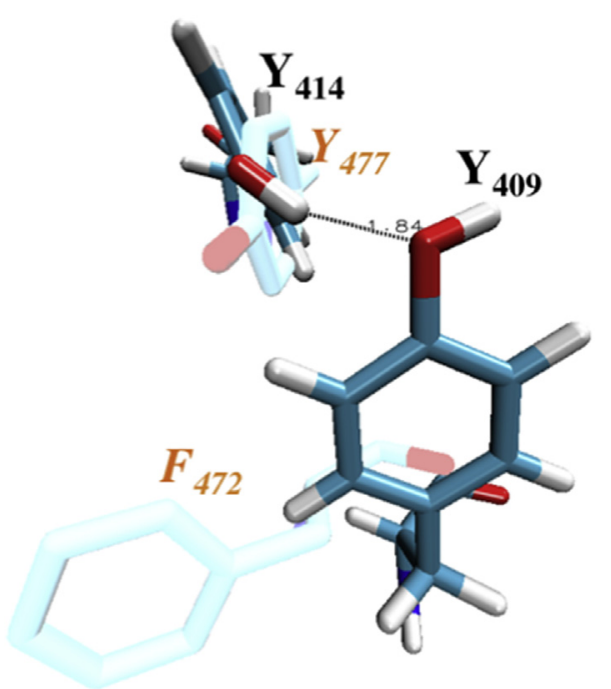

Fig. 11. Hydrogen bond interactions between the $Y_{414}$ catalytic tyrosine and the $Y_{409}$ of Ap-B superposed with that of corresponding amino acids of the human Ap-N ( $\mathrm{Y}_{477}$ and $\left.\mathrm{F}_{472} ; 4 \mathrm{FYQ}\right)$. A distance of $1.84 \AA$ is determined for the hydrogen bond between $\mathrm{Y}_{409}$ and $\mathrm{Y}_{414}$. Images of structures were performed using the Visual Molecular dynamics (VMD) software. 
thus proposed [38]. From all of these observations, a question arises and for which a response will be probably brought in the future: Is the hydroxyl group of the tyrosine residue (Ap-B, $Y_{409}$ ) necessary for the hydrolysis of peptides by the M1 aminopeptidases with three structural domains?

$\mathrm{Y}_{409}$ is replaced by a phenylalanine in some $\mathrm{LTA}_{4} \mathrm{H}$ sequences and in all primary structures of aminopeptidases with four domains (e.g. Ap-N; Fig. 1B). The supplementary domain governs the existence of closed and open conformations. The superposition of the Ap-B 3D model with the closed conformation of the Ap- $\mathrm{N}$ crystallographic structure (pdb: 4FYQ) shows an inverse orientation of the $\mathrm{F}_{472}$ residue of Ap-N compared to the corresponding $\mathrm{Y}_{409}$ of Ap-B (Fig. 11). $\mathrm{F}_{472}$ is farthest from the catalytic $\mathrm{Y}_{477}$, which could promote the mobility of this catalytic tyrosine as observed for closed and open structures of the ERAP1 and ERAP2 aminopeptidases [24]. Consequently, other experiments, especially with different peptide substrates, will be necessary to highlight the subtle differences governing the role of the tyrosine vs. phenylalanine in the M1 aminopeptidase catalytic mechanisms.

\subsection{Tyrosine 281}

Both $\mathrm{Y}_{281}$ and $\mathrm{Y}_{441}$ are located rather near the surface of Ap-B. In contrast to $Y_{229}$ and $Y_{414}$, which have a concerted function in the catalytic mechanism of enzymes of the M1 family, it is difficult to evaluate whether $Y_{281}$ and $Y_{441}$ establish direct or indirect interactions with the substrate or with amino acids present in the first shell of the active site.

The $Y_{281} \mathrm{~F}$ mutation affects significantly the enzyme activity, that drops rapidly and catalytic parameters could not be obtained. The role of this residue could be a contribution to the maintenance of a spatial arrangement important for the function of some catalytic amino acids. Notably, as $Y_{281}$ is in proximity of $E_{301}$ residue in the GAMEN motif, it can be of interest to analyze the amino acid environment and its structural influence. As observed on the model of the Ap-B (Fig. 12), the hydroxyl group of $Y_{281}$ is able to establish a hydrogen bond with the carbonyl of $R_{285}$. This latter residue is conserved in the sequences of Ap-B and RNPEP-L1 but it is replaced

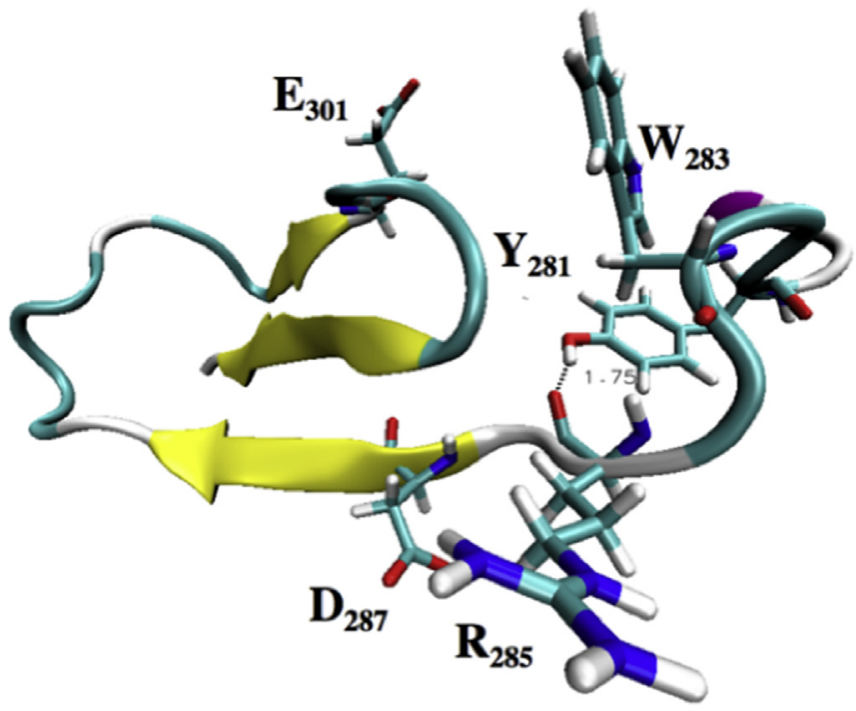

Fig. 12. Proximity and chemical interactions between $Y_{281}$ and $R_{285}$. A salt bridge could be established between $R_{285}$ and $D_{287}$. These interactions could participate to the stabilization of the small beta sheet that exposes the $E_{301}$ residue in the active site of the Ap-B. A distance of $1.75 \AA$ is determined for the hydrogen bond between the hydroxyl of $Y_{281}$ and the carbonyl of $R_{285}$. Images of structures were performed using the Visual Molecular dynamics (VMD) software. by a glutamine in $\mathrm{LTA}_{4} \mathrm{H}$ and by a lysine in the other aminopeptidases. $Y_{281}$ and $R_{285}$ are located on a loop in proximity of a $\beta$ sheet, which expose $E_{301}$ in the catalytic site (Fig. 12). This H-bond could participate to the stabilization of this functional $\beta$ sheet. Other chemical interactions form a network that could stabilize this functional structure. Especially, an ionic interaction between $R_{285}$ and $\mathrm{D}_{287}$ (a residue conserved in all sequences) is identifiable, as well as an aromatic interaction between $\mathrm{Y}_{281}$ and $\mathrm{W}_{283}$ in the aminopeptidases with three domains. In the aminopeptidases with four domains, this interaction is observed with the tryptophan residue located just after the (G/A/H/V) (G/A)MEN motif (Fig. 2).

In addition, $R_{285}$ in Ap-B could also be implicated in a cation $\pi$ interaction with $\mathrm{Y}_{281}$, upon a reorientation of its side chain resulting from the tilt of the loop to which it belongs. This dynamic process could contribute to the conformational arrangement of the catalytic site. Other mutagenesis experiments and structural analyses will be needed to verify the role of $Y_{281}$ in important structural and functional interactions necessary for the enzyme catalytic mechanism.

\subsection{Tyrosine 441}

The $\mathrm{Y}_{441} \mathrm{~F}$ mutation reduces by $66 \%$ the catalytic capacity of the Ap-B. The environment of $\mathrm{Y}_{441}$ is highly hydrophobic with possibility of stacking with numerous phenylalanine residues (not shown). Moreover, a hydrogen bond can be suspected between the hydroxyl group of $Y_{441}$ and the carbonyl of $D_{454}$ (3.63 Å; Fig. 13). This aspartate residue seems to be important, since it is conserved in the sequences of the vertebrate aminopeptidases of the M1 family $\left(\mathrm{LTA}_{4} \mathrm{H}, \mathrm{D}_{423}\right)$.

For these aminopeptidases, it appears that the strength of the hydrogen bond network established with this tyrosine residue could vary depending on the environment. Notably for $\mathrm{LTA}_{4} \mathrm{H}$, the hydrogen bond cannot be visualized between the hydroxyl group of $\mathrm{Y}_{410}$ and the carbonyl of $\mathrm{D}_{423}$ but with the nitrogen of $\mathrm{H}_{320}$ (4.16 $\AA$; Fig. 13), a histidine residue that is generally replaced by a phenylalanine in other aminopeptidases (Fig. 2). Such an interaction could indirectly participate to the arrangement of the $\mathrm{Zn}^{2+}$ catalytic atom in the active site. Indeed, $\mathrm{H}_{320}$ is located in proximity of $\mathrm{E}_{318}$, one of the essential residues of the active site as chelator of the $\mathrm{Zn}^{2+}$ atom.

Thus in the M1 family of aminopeptidases, the role of $Y_{441}$ could be in relation with a difference in substrate specificity and/or in catalytic efficiencies. Other more detailed studies, in particular

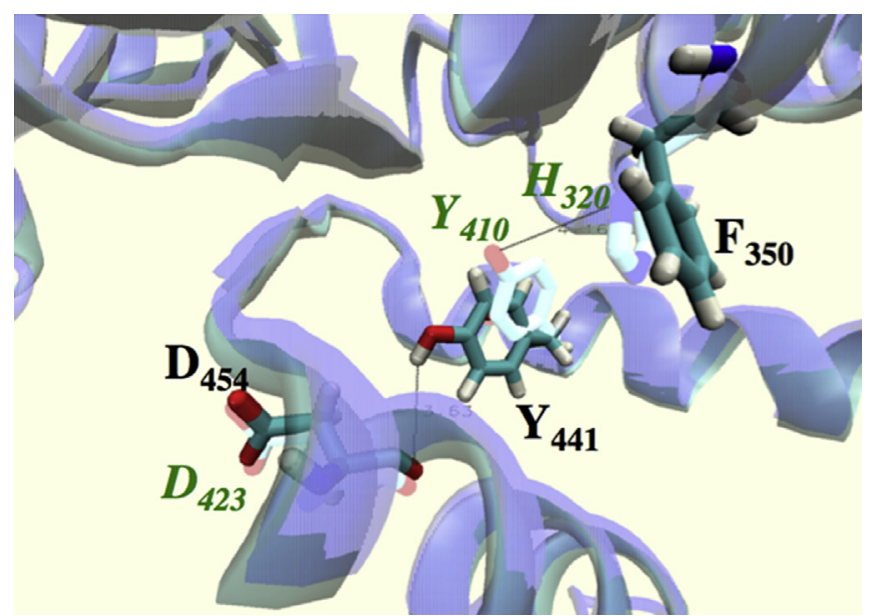

Fig. 13. Superposition of the structures of $A p-B$ and $L_{T} A_{4} H$ (pdb: 3B7T) showing a potential hydrogen bond between the hydroxyl group of $\mathrm{Y}_{441}$ and the carbonyl of $\mathrm{D}_{454}$ (3.63 $\AA, A p-B)$. In $\mathrm{LTA}_{4} \mathrm{H}$, no such hydrogen bond between $\mathrm{Y}_{410}$ and $\mathrm{D}_{423}$ is identified, on the other hand this bond could be established with $\mathrm{H}_{320}\left(4.16 \AA \AA\right.$; Ap-B, $\mathrm{F}_{350}$ ). Images of structures were performed using the Visual Molecular dynamics (VMD) software. 
molecular dynamics simulations, will be necessary to understand the complex role of this tyrosine residue in the enzymatic reaction of each aminopeptidases of the M1 family.

In conclusion, this work highlights the essential function of residues from second shell and of amino acids distant from the active site in enzyme catalysis. In particular, the tyrosine residues of which the hydroxyl groups forming hydrogen bonds are necessary for the enzymatic catalysis. Since these enzymes are involved in important physiological roles, this approach should help to the conception of highly specific inhibitors that could be used in a therapeutic research pathway.

\section{Conflict of interest}

\section{There is no conflict of interest.}

\section{Acknowledgments}

This manuscript is written in memory of Paul Cohen who initiated this work in the early 1990s. We also acknowledge the expert technical contributions of G. Bolbach and G. Clodic (IBPS platform of mass spectrometry and proteomics) and C. Piesse (IBPS platform of Peptide Synthesis, Molecular Interactions and real-time PCR). We also wish to warmly thank Pierre Nicolas for his constant support and advices throughout this work. This work was supported by grants from the University Pierre et Marie Curie.

\section{References}

[1] S. Cadel, A.R. Pierotti, T. Foulon, C. Créminon, N. Barré, D. Segrétain, P. Cohen Aminopeptidase B in the rat testes: isolation, functional properties and cellular localization in the seminiferous tubules, Mol. Cell. Endocrinol. 110 (1995) 149-160.

[2] T. Foulon, S. Cadel, V. Chesneau, M. Draoui, A. Prat, P. Cohen, Two novel metallopeptidases with a specificity for basic residues. Functional properties, structure and cellular distribution, Ann. N. Y. Acad. Sci. 780 (1996) 96-106.

[3] C. Piesse, M. Tymms, E. Garrafa, C. Gouzy, M. Lacasa, S. Cadel, P. Cohen, T. Foulon, Human aminopeptidase B [rnpep] on chromosome 1q32.2: complementary DNA, genomic structure and expression, Gene 292 (2002) $129-140$.

[4] C. Piesse, S. Cadel, C. Gouzy-Darmon, J.C. Jeanny, V. Carrière, D. Goidin, L. Jonet, D. Gourdji, P. Cohen, T. Foulon, Expression and cellular distribution of aminopeptidase B in the developing and adult rat retina, Exp. Eye Res. 79 (2004) 639-648.

[5] G. Fontes, A.D. Lajoix, F. Bergeron, S. Cadel, A. Prat, T. Foulon, R. Gross, S. Dalle, D. Le-Nguyen, F. Tribillac, D. Bataille, Miniglucagon-generating endopeptidase, which processes glucagon in miniglucagon is composed of NRD convertase and aminopeptidase B, Endocrinology 146 (2005) 702-712.

[6] M.C. Beinfeld, L. Funkelstein, T. Foulon, S. Cadel, K. Kitagawa, T. Toneff, T. ReinHeckel, C. Petres, V. Hook, Cathepsin L plays a major role in cholecystokinin production in mouse brain cortex and in pituitary AtT20-cells: protease gene knockout and inhibitor studies, Peptide 30 (1) (2009) 882-1891.

[7] S.R. Hwang, A. O'Neill, S. Bark, T. Foulon, V. Hook, Secretory vesicle aminopeptidase B related to neuropeptide processing: molecular identification and subcellular localization to enkephalin- and NPY-containing chromaffin granules, J. Neurochem. 100 (2007) 1340-1350.

[8] M. Kouach, B. Desbuquois, F. Authier, Endosomal proteolysis of internalized [ArgA0]-human insulin at neutral $\mathrm{pH}$ generates the mature insulin peptide in rat liver in vivo, Diabetologia 12 (2009) 2621-2632.

[9] S. Urban, K. Textoris-Taube, B. Reimann, K. Janek, T. Dannenberg, F. Ebstein, C. Seifert, F. Zhao, J.H. Kessler, A. Halenius, P. Henklein, J. Paschke, S. Cadel H. Bernhard, F. Ossendorp, T. Foulon, D. Schadendorf, A. Paschen, U. Seifert, The efficiency of human cytomegalovirus pp65495-503 CD8+ T cell epitope generation is determined by the balanced activities of cytosolic and endoplasmic reticulum-resident peptidases, J. Immunol. 189 (2012) 529-538.

[10] S. Cadel, T. Foulon, A. Viron, S. Midol-Monnet, A. Balogh, N. Noel, P. Cohen, Aminopeptidase B from the rat testis is structurally and enzymatically related to leukotriene-A4 hydrolase, Proc. Natl. Acad. Sci. 94 (1997) 2963-2968.

[11] N.M. Hooper, Families of zinc metalloproteases, FEBS Lett. 354 (1994) 1-6.

[12] F. Tholander, A. Muroya, B.P. Roques, M.C. Fournié-Zaluski, M.M. Thunnissen, J.Z. Haeggström, Structure-based dissection of the active site chemistry of leukotriene $\mathrm{A}_{4}$ hydrolase: implications for M1 aminopeptidases and inhibitor design, Chem. Biol. 15 (2008) 920-929.

[13] G. Vazeux, X. Iturrioz, P. Corvol, C. Llorens-Cortes, A glutamate residue contributes to the exopeptidase specificity in aminopeptidase A, Biochem. J. 334 (1998) 407-413.
[14] X. Iturrioz, R. Rozenfeld, A. Michaud, P. Corvol, C. Llorens-Cortes, Study of asparagine 353 in aminopeptidase A: characterization of a novel motif [GXMEN] implicated in exopeptidase specificity of monozinc aminopeptidases, Biochemistry 40 (2001) 14440-14448.

[15] P.C. Rudberg, F. Tholander, M. Thunnissen, J.Z. Haeggström, Leukotriene/ aminopeptidase. Glutamate 271 is a catalytic residue with specific roles in two distinct enzyme mechanisms, J. Biol. Chem. 277 (2002) 1398-1404.

[16] V.L. Pham, C. Gouzy-Darmon, J. Pernier, C. Hanquez, V. Hook, M.C. Beinfeld, P. Nicolas, C. Etchebest, T. Foulon, S. Cadel, Mutation in the substrate-binding site of aminopeptidase B confers new enzymatic properties, Biochimie 4 (2011) 730-741.

[17] L. Chen, Y.L. Lin, G. Peng, F. Li, Structural basis for multifunctional roles of mammalian aminopeptidase N, Proc. Natl. Acad. Sci. U. S. A. 109 (2012) 17966-17971.

[18] M.M. Thunnissen, P. Nordlund, J.Z. Haeggström, Crystal structure of human leukotriene A4 hydrolase, a bifunctional enzyme in inflammation, Nat. Struct. Biol. 8 (2001) 131-135.

[19] A. Addlagatta, L. Gay, B.W. Matthews, Structure of aminopeptidase N from Escherichia coli suggests a compartmentalized, gated active site, Proc. Natl. Acad. Sci. 103 (2006) 13339-13344.

[20] B. Nocek, R. Mulligan, M. Bargassa, F. Collart, A. Joachimiak, Crystal structure of aminopeptidase $\mathrm{N}$ from human pathogen Neisseria meningitidis, Proteins 70 (2008) 273-279.

[21] S. McGowan, C.J. Porter, J. Lowther, C.M. Stack, S.J. Golding, T.S. SkinnerAdams, K.R. Trenholme, F. Teuscher, S.M. Donnelly, J. Grembecka, A. Mucha, P. Kafarski, R. Degori, A.M. Buckle, D.L. Gardiner, J.C. Whisstock, J.P. Dalton, Structural basis for the inhibition of the essential Plasmodium falciparum M1 neutral aminopeptidase, Proc. Natl. Acad. Sci. U. S. A 106 (2009) 2537-2542.

[22] A.H. Wong, D. Zhou, J.M. Rini, The X-ray crystal structure of human aminopeptidase $\mathrm{N}$ reveals a novel dimer and the basis for peptide processing, J. Biol. Chem. 287 (2012) 36804-36813.

[23] T.T. Nguyen, S.C. Chang, I. Evnouchidou, I.A. York, C. Zikos, K.L. Rock, A.L. Goldberg, E. Stratikos, L.J. Stern, Structural basis for antigenic peptide precursor processing by the endoplasmic reticulum aminopeptidase ERAP1, Nat. Struct. Mol. Biol. 18 (2011) 604-613.

[24] J.R. Birtley, E. Saridakis, E. Stratikos, I.M. Mavridis, The crystal structure of human endoplasmic reticulum aminopeptidase 2 reveals the atomic basis for distinct roles in antigen processing, Biochemistry 51 (2012) 286-295.

[25] A. Wetterholm, J.Z. Haeggström, Leukotriene A4 hydrolase: an anion activated peptidase, Biochim. Biophys. Acta 1123 (1992) 275-281.

[26] R.J. Snelgrove, P.L. Jackson, M.T. Hardison, B.D. Noerager, A. Kinloch, A. Gaggar, S. Shastry, S.M. Rowe, Y.M. Shim, T. Hussell, J.E. Blalock, A critical role for $\mathrm{LTA}_{4} \mathrm{H}$ in limiting chronic pulmonary neutrophilic inflammation, Science 330 (2010) 90-94.

[27] R.J. Snelgrove, Leukotriene A4 hydrolase: an anti-inflammatory role for a proinflammatory enzyme, Thorax 66 (2011) 550-551.

[28] V.L. Pham, M.S. Cadel, C. Gouzy-Darmon, C. Hanquez, M.C. Beinfeld, P. Nicolas, C. Etchebest, T. Foulon, Aminopeptidase B, a glucagon-processing enzyme: site directed mutagenesis of the $\mathrm{Zn}^{2+}$ binding motif and molecular modeling, BMC Biochem. 8 (2007) 21.

[29] O.S. Du, Q.Y. Wang L.Q. Du, D. Chen, R.B. Huang, Theoretical study on the polar hydrogen-pi [Hp-pi] interactions between protein side chains, Chem. Cent. J. 7 (2013) 92.

[30] M. Andberg, A. Wetterholm, J.Z. Haeggström, Mutation of Tyr-383 in leukotriene A4 hydrolase: effects on enzyme activities, Adv. Exp. Med. Biol. 433 (1997) 149-152.

[31] M.W. Thompson, E.D. Archer, C.E. Romer, R.L. Seipelt, A conserved tyrosine residue of Saccharomyces cerevisiae leukotriene $A_{4}$ hydrolase stabilizes the transition state of the peptidase activity, Peptides 27 (2006) 1701-1709.

[32] F.W. Tsui, N. Haroon, J.D. Reveille, P. Rahman, B. Chiu, H.W. Tsui, R.D. Inman, Association of an ERAP1 ERAP2 haplotype with familial ankylosing spondylitis, Ann. Rheum. Dis. 69 (2010) 733-736.

[33] M.P. Johnson, L.T. Roten, T.D. Dyer, C.E. East, S. Forsmo, J. Blangero, S.P. Brennecke, R. Austgulen, E.K. Moses, The ERAP2 gene is associated with preeclampsia in Australian and Norwegian populations, Hum. Genet. 126 (2009) 655-666.

[34] I. Evnouchidou, J. Birtley, S. Seregin, A. Papakyriakou, E. Zervoudi, M. Samiotaki, G. Panayotou, P. Giastas, O. Petrakis, D. Georgiadis, A. Amalfitano, E. Saridakis, I.M. Mavridis, E. Stratikos, A common single nucleotide polymorphism in endoplasmic reticulum aminopeptidase 2 induces a specificity switch that leads to altered antigen processing, J. Immunol. 189 (2012) 2383-2392.

[35] M. Blomster, A. Wetterholm, M.J. Mueller, J.Z. Haeggström, Evidence for a catalytic role of tyrosine 383 in the peptidase reaction of leukotriene A4 hydrolase, Eur. J. Biochem. 231 (1995) 528-534.

[36] M.J. Mueller, M.B. Andberg, B. Samuelsson, J.Z. Haeggström, Leukotriene A4 hydrolase, mutation of tyrosine 378 allows conversion of leukotriene A4 into an isomer of leukotriene B4, J. Biol. Chem. 271 (1996) 24345-24348.

[37] F. Strömberg, M. Hamberg, U. Rosenzvist, S.E. Dahlén, J.Z. Haeggström, Formation of a novel enzymatic metabolite of leukotriene A4 in tissues of Xenopus laevis, Eur. J. Biochem. 238 (1996) 599-605.

[38] A. Stsiapanava, F. Tholander, R.B. Kumar, A.A. Qureshi, D. Niegowski, M. Hasan, M. Thunnissen, J.Z. Haeggström, A. Rinaldo-Matthis, Product formation controlled by substrate dynamics in leukotriene A4 hydrolase, Biochim. Biophys. Acta 1844 (2014) 439-446. 